Review

\title{
Ubiquitous but Ignored? A Case of Water Beetle in Southeastern Europe
}

\author{
Vlatka Mičetić Stanković ${ }^{1, *(D)}$, Branka Bruvo Mađarić ${ }^{2}$ and Mladen Kučinić $^{3}$ (D) \\ 1 Croatian Natural History Museum, Demetrova 1, HR-10000 Zagreb, Croatia \\ 2 Ruđer Bošković Institute, Bijenička Cesta 54, HR-10000 Zagreb, Croatia; Branka.Bruvo.Madjaric@irb.hr \\ 3 Department of Biology, Faculty of Science, University of Zagreb, Rooseveltov trg 6, HR-10000 Zagreb, Croatia; \\ mladen.kucinic@biol.pmf.hr \\ * Correspondence: vlatkams@hpm.hr
}

Citation: Mičetić Stanković, V.; Bruvo Mađarić, B.; Kučinić, M. Ubiquitous but Ignored? A Case of Water Beetle in Southeastern Europe. Diversity 2022, 14, 26. https://doi.org/ $10.3390 / \mathrm{d} 14010026$

Academic Editor: Michael Wink

Received: 10 December 2021

Accepted: 24 December 2021

Published: 31 December 2021

Publisher's Note: MDPI stays neutral with regard to jurisdictional claims in published maps and institutional affiliations.

Copyright: (C) 2021 by the authors. Licensee MDPI, Basel, Switzerland. This article is an open access article distributed under the terms and conditions of the Creative Commons Attribution (CC BY) license (https:// creativecommons.org/licenses/by/ $4.0 /)$.

\begin{abstract}
Although freshwater habitats, especially springs, are widely recognized as top-priority habitats for monitoring and conservation procedures, their fauna, especially water beetles, are still poorly studied in the southeastern part of Europe. Thus, the dominant water beetle in these habitats, E. bosnica (Zaitzev, 1908) (Insecta: Coleoptera: Elmidae), has been completely ignored and misidentified. This study represents the first review of its taxonomy and its population and ecological traits. Both published and unpublished data are presented and discussed, as well as the results of field sampling in 46 springs and other waterbodies conducted in this region from 2004 to 2019. The identification characters of the male genitalia and the first DNA barcode of the species are presented. The results confirm the close phylogenetic relationship of E. bosnica with E. aenea (Müller, 1806) and E. rioloides (Kuwert, 1890). The species proved to be a useful environmental descriptor and can easily be used as a biological indicator due to its easy identification. The species shows remarkable sensitivity to environmental conditions and inhabits sites that are potentially under increased anthropogenic pressure and could disappear at an alarming rate. Thus, karstic habitats should be included in future conservation and monitoring procedures in this part of Europe.
\end{abstract}

Keywords: crenal fauna; E. bosnica; karst; first review; overlooked

\section{Introduction}

People's awareness of the importance of biodiversity for our planet rapidly advances each day, but the number of species continues to decline [1]. The pressure on biodiversity is too large, especially due to intensive land use and climate change. Biodiversity data are patchy and biased, and their sensitivity varies by geographical region (Reference [1] and the references therein). Southeastern Europe (SE), especially the Mediterranean part, is exposed to strong anthropogenic pressures, due to its long history of overpopulation and the increasing demand for water resources every year [2]. Various studies [2-5] have already highlighted the importance of freshwater habitats, especially springs, as they serve as refugia for plants and animals and are hotspots of biodiversity. The water there is constantly available and contrasts with an often completely different environment. Therefore, such habitats harbor species that would definitely disappear within a short time if the freshwater habitat dried up [2].

One of the most common inhabitants of springs, rivers and streams are riffle beetles (Insecta: Coleoptera: Elmidae). They are small-bodied (2-3 $\mathrm{mm}$ on average) aquatic insects with long legs and claws that enable them to resist water currents [6]. A total of 10 genera and more than 40 species are known in Europe so far [7]. They are classified as "true water beetles" [6]. Their life cycle is quite complex and includes both aquatic and riparian zones [8], and they take up oxygen directly from the surrounding water $[9,10]$. Elmidae are often used as biological indicators due to their sensitivity to environmental conditions [6-10]. Elliott [8] even noted that they are a potential indicator of climate change. 
Although the freshwater fauna in Southeastern Europe has been studied for more than a century (e.g., Refs. [11,12]), the water beetles, and especially the Elmidae, have been more or less completely ignored. Mičetić Stanković et al. [13-16] and Novaković et al. [17-19] first started systematic studies of the family Elmidae in this area. In Croatia, 24 species of the family have been recorded so far $[13,15]$, while similar lists for other countries in this region are still lacking. These recent studies have shown, among other things, that the karst springs of Southeastern Europe are inhabited exclusively by a single species of Elmidae, i.e., E. bosnica (Zaitzev, 1908) (Figure 1), which can be extremely abundant in certain habitats $[13,14,16]$. This species has been completely neglected and misidentified due to a lack of data on biological or ecological characteristics in the literature. Apfelbeck [12], for example, misidentified the species in the Spring of the Bistrica River as Elmis aenea (Müller, 1806) [20], while Matoničkin et al. [21] and Habdija et al. [22] misidentified it in the spring sites of Plitvice Lakes NP, Croatia, as E. maugetii Latreille, 1802. The misidentifications were probably the result of identifications based only on external morphology and not on the morphology of the male genitalia [13]. Zaitzev [23] first described the species E. bosnica as Helmis maugetii bosnica in Bosnia and Herzegovina. The species belongs to the BalkanoTuranian chorotype $[14,16]$ and is distributed in Albania, Armenia, Bosnia and Herzegovina, Bulgaria, Croatia, Greece, Iran, the Republic of North Macedonia, Montenegro, Russia (South European Territory), Serbia and Turkey [7].

The territory of Europe is very diverse in terms of its geology, hydrology and hydrogeology. Altogether, 21.6\% of the European land surface consists of carbonate rocks, mostly karstified with karst aquifers [24]. In Europe's southeastern part, large areas represent "continuous carbonate rocks", which are prone to dissolution and defined as karst habitats. This territory is characterized by diverse morphological, hydrological and hydrogeological formations [25-27]. Karst freshwater habitats, especially springs, are nowadays under particular anthropogenic pressure [2,5,28,29], mainly due to their specific hydrology based on a combination of high rock solubility and well-developed fissured porosity, as well as water consumption, diversion of spring water or climate change [30,31]. Gaston and David [32] have identified the Dinaric Mountain system (the Dinaric Karst) in Southeastern Europe as a hotspot of European biodiversity. Several studies have addressed the occurrence of high endemism in the freshwater and subterranean fauna there, with the presence of "refugia within refugia" pattern for particular taxa [33-38]. Although freshwater springs are recognized as important habitats from both anthropogenic and biological perspectives [4,7], they remain poorly studied, and their biotic communities have yet to be investigated [39].

DNA barcoding [40] is a widely used method in taxonomy and species identification in various studies and projects, but so far there are only a few studies on European representatives of the Elmidae (see Refs. [15,41-43] and barcoding initiatives, Refs. [44,45]). In DNA barcoding, reliable species identification is enabled by the high interspecific divergence and low intraspecific variability of the $\sim 650$ bp long mitochondrial (mt) cytochrome oxidase gene subunit I (COI) fragment [46]. DNA barcoding has proven particularly useful when dealing with siblings or morphologically ambiguous species, which are quite common in water beetles (see Refs. [47-49]).

Considering all of the abovementioned, we have decided to provide the first review of the biology and ecology of the widely distributed, but overlooked E. bosnica (Zaitzev, 1908), in freshwater habitats in Southeastern Europe. To preclude future misidentification of the species, we provide (a) an identification guide comparing the male genitalia of three Elmis species that might occur in the same habitat and (b) the first DNA barcode. Both published and unpublished data on the distribution, population and ecological characteristics of the species are presented, analyzed and discussed. 


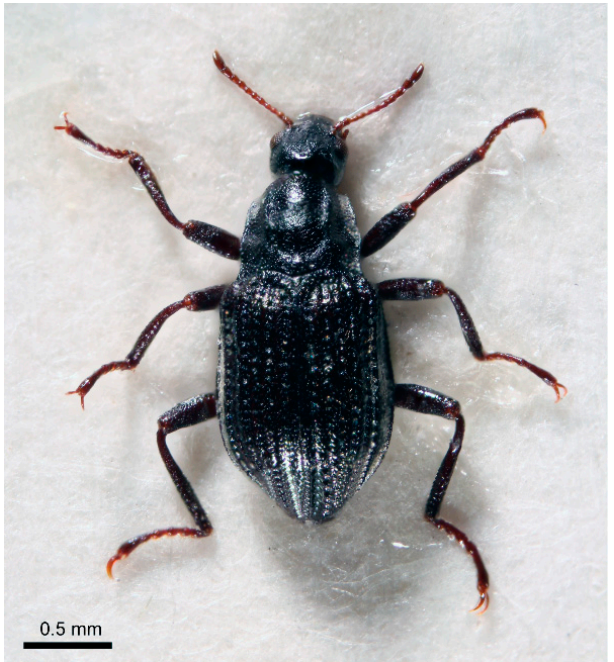

(a)

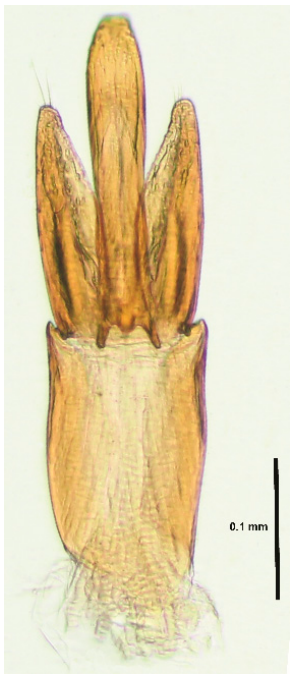

(b)

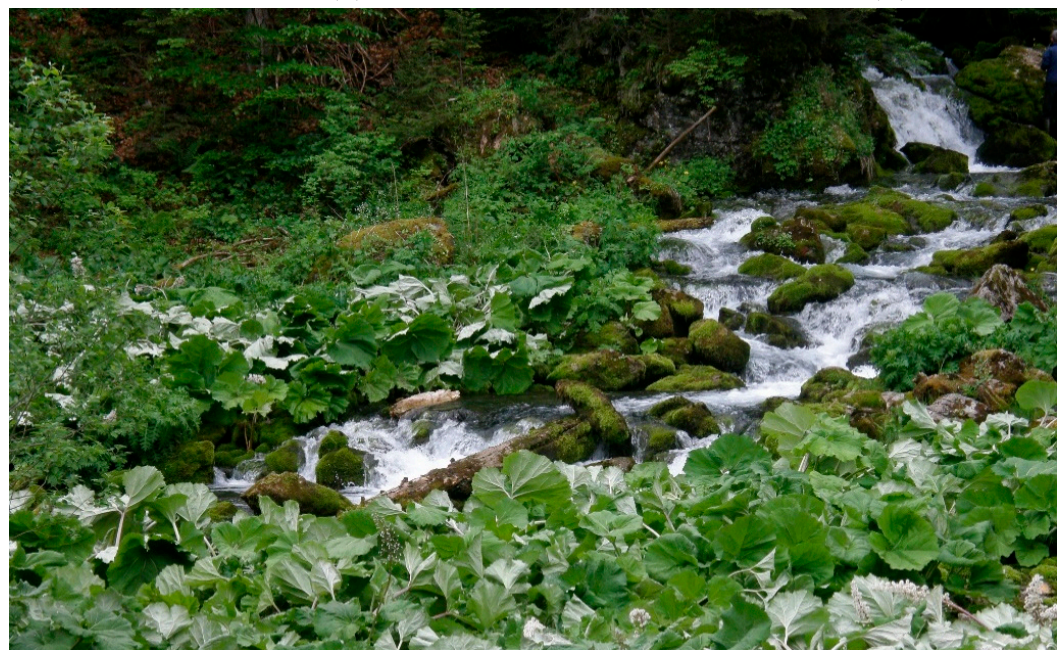

(c)

Figure 1. E. bosnica (Zaitzev, 1908): (a) habitus; (b) aedeagus—ventral side; (c) typical habitat: Spring of the Ibra River, Montenegro.

\section{Material and Methods}

\subsection{Study Area}

The territory of Europe is a mosaic of different geological, geomorphological and climatic characters [50]. Southeastern Europe lies at the crossroads of three continental regions with climatically distinct areas: the Mediterranean, the Alpine and the Continental [26,51]. In the area investigated in this study, Alpine and Mediterranean climates overlap, with temperature variations determined by latitude and altitude, but with inversions typical of the Dinarid Alps. Annual precipitation shows high variability throughout Southeastern Europe, with the highest mean over $4600 \mathrm{~mm}$ /year in Montenegro, to less than $1000 \mathrm{~mm} /$ year on the Adriatic coast [26]. The Dinaric Mountain system or Dinaric Alps (the Dinaric Karst) represents the largest continuous karst surface in Europe and is among the largest karst surfaces in the world [24]. It extends over approximately $56,000 \mathrm{~km}^{2}$ along the $800 \mathrm{~km}$ arc from Trieste, Italy, in the north, across most of Slovenia, Croatia and Bosnia and Herzegovina to Albania in the south $[27,29,52]$ (Figure 2). It is considered a karst prototype (locus typicus) with typical karst formations and hydrogeological and morphological phenomena [25]. The riverbeds in the northern region of the Republic of North Macedonia are formed as canyons with karst relief shapes, such as caves [26]. 


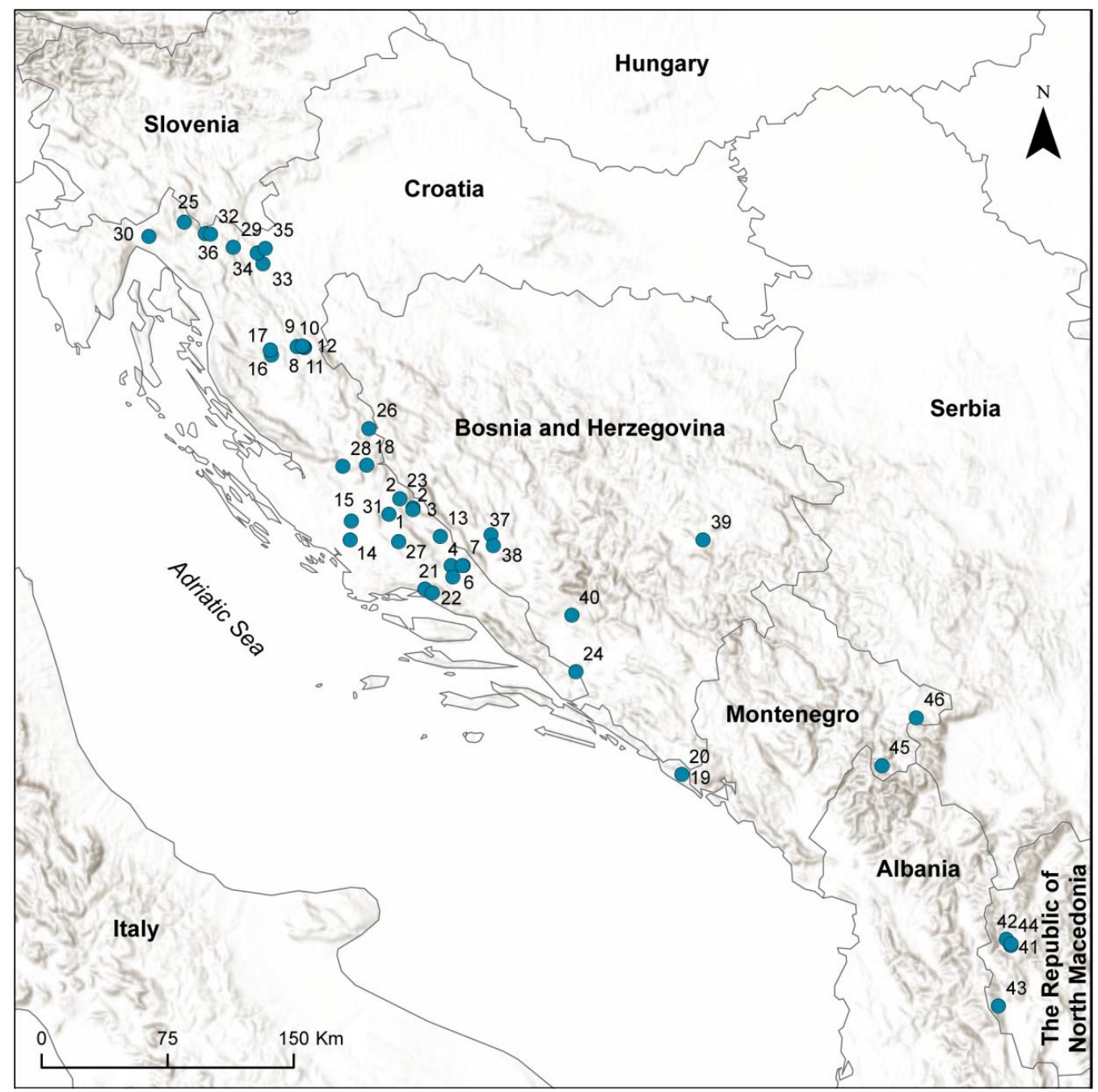

Figure 2. Distribution of E. bosnica (Zaitzev, 1908), in Southeastern Europe. Locality codes are the same as in Table 1.

Table 1. Characteristics of sampling sites in Southeastern Europe, where E. bosnica (Zaitzev, 1908), was recorded from 2004 to 2019. Abbreviations: C, locality code; MWT, mean water temperature.

\begin{tabular}{|c|c|c|c|c|c|c|c|}
\hline C & Sampling Site & Latitude & Longitude & $\begin{array}{l}\text { Altitude } \\
\text { (m) }\end{array}$ & Habitat Type & $\begin{array}{c}\text { Water } \\
\text { Constancy }\end{array}$ & $\begin{array}{c}\text { App. } \\
\text { MWT }\left({ }^{\circ} \mathrm{C}\right)\end{array}$ \\
\hline & CROATIA & & & & & & \\
\hline 1 & Cetina River, Glavaš spring & $\mathrm{N} 43^{\circ} 58^{\prime} 36.00^{\prime \prime}$ & $\mathrm{E} 16^{\circ} 25^{\prime} 48.00^{\prime \prime}$ & 385 & $\begin{array}{l}\text { limnocrene } \\
\text { spring }\end{array}$ & permanent & 9.00 \\
\hline 2 & Cetina River, Crveni Most & $\mathrm{N} 43^{\circ} 58^{\prime} 05.00^{\prime \prime}$ & $\mathrm{E} 16^{\circ} 25^{\prime} 53.00^{\prime \prime}$ & 365 & upper reach & permanent & 9.00 \\
\hline 3 & Cetina River, Obrovac Sinjski & $\mathrm{N} 43^{\circ} 40^{\prime} 01.00^{\prime \prime}$ & $\mathrm{E} 16^{\circ} 41^{\prime} 04.00^{\prime \prime}$ & 300 & middle reach & permanent & 10.00 \\
\hline 4 & Cetina River, Preočki Most & $\mathrm{N} 43^{\circ} 57^{\prime} 59.00^{\prime \prime}$ & $\mathrm{E} 16^{\circ} 25^{\prime} 53.00^{\prime \prime}$ & 370 & upper reach & permanent & 9.00 \\
\hline 5 & Cetina River, Trilj & $\mathrm{N} 43^{\circ} 36^{\prime} 21.00^{\prime \prime}$ & $\mathrm{E} 16^{\circ} 43^{\prime} 46.00^{\prime \prime}$ & 295 & middle reach & permanent & 10.00 \\
\hline 6 & Ruda River, spring & $\mathrm{N} 43^{\circ} 40^{\prime} 07.00^{\prime \prime}$ & $\mathrm{E} 16^{\circ} 47^{\prime} 56.00^{\prime \prime}$ & 320 & $\begin{array}{l}\text { limnocrene } \\
\text { spring }\end{array}$ & permanent & 12.00 \\
\hline 7 & $\begin{array}{l}\text { Ruda River, } 500 \mathrm{~m} \\
\text { downstream of spring }\end{array}$ & $\mathrm{N} 43^{\circ} 40^{\prime} 07.50^{\prime \prime}$ & $\mathrm{E} 16^{\circ} 47^{\prime} 49.20^{\prime \prime}$ & 330 & upper reach & permanent & 12.00 \\
\hline 8 & $\begin{array}{l}\text { Plitvice Lakes NP, Bijela rijeka } \\
\text { River spring }\end{array}$ & $\mathrm{N} 44^{\circ} 50^{\prime} 05.00^{\prime \prime}$ & $\mathrm{E} 15^{\circ} 33^{\prime} 43.00^{\prime \prime}$ & 720 & helocrene spring & permanent & 7.00 \\
\hline 9 & $\begin{array}{l}\text { Plitvice Lakes NP, Bijela rijeka } \\
\text { River Upper Reach }\end{array}$ & $\mathrm{N} 44^{\circ} 50^{\prime} 04.00^{\prime \prime}$ & $\mathrm{E} 15^{\circ} 33^{\prime} 33.00^{\prime \prime}$ & 715 & upper reach & permanent & 7.50 \\
\hline 10 & $\begin{array}{l}\text { Plitvice Lakes NP, Crna rijeka } \\
\text { River spring }\end{array}$ & $\mathrm{N} 44^{\circ} 49^{\prime} 44.46^{\prime \prime}$ & $\mathrm{E} 15^{\circ} 36^{\prime} 50.05^{\prime \prime}$ & 680 & rheocrene spring & permanent & 8.00 \\
\hline
\end{tabular}


Table 1. Cont.

\begin{tabular}{|c|c|c|c|c|c|c|c|}
\hline $\mathrm{C}$ & Sampling Site & Latitude & Longitude & $\begin{array}{l}\text { Altitude } \\
\quad(\mathrm{m})\end{array}$ & Habitat Type & $\begin{array}{l}\text { Water } \\
\text { Constancy }\end{array}$ & $\begin{array}{c}\text { App. } \\
\text { MWT }\left({ }^{\circ} \mathrm{C}\right)\end{array}$ \\
\hline 11 & $\begin{array}{l}\text { Plitvice Lakes NP, Crna rijeka } \\
\text { River Middle Reach }\end{array}$ & $\mathrm{N} 44^{\circ} 50^{\prime} 10.00^{\prime \prime}$ & $\mathrm{E} 15^{\circ} 36^{\prime} 30.00^{\prime \prime}$ & 670 & middle reach & permanent & 8.00 \\
\hline 12 & $\begin{array}{l}\text { Plitvice Lakes NP, Crna rijeka } \\
\text { River Lower Reach }\end{array}$ & $\mathrm{N} 44^{\circ} 50^{\prime} 22.00^{\prime \prime}$ & $\mathrm{E} 15^{\circ} 35^{\prime} 59.00^{\prime \prime}$ & 665 & lower reach & permanent & 8.00 \\
\hline 13 & Vojskova River & $\mathrm{N} 43^{\circ} 49^{\prime} 25.60^{\prime \prime}$ & $\mathrm{E} 16^{\circ} 37^{\prime} 54.60^{\prime \prime}$ & 360 & upper reach & permanent & 10.00 \\
\hline 14 & $\begin{array}{l}\text { Krka River NP, Skradinski } \\
\text { Buk waterfall }\end{array}$ & $\mathrm{N} 43^{\circ} 48^{\prime} 11.26^{\prime \prime}$ & $\mathrm{E} 15^{\circ} 57^{\prime} 56.29^{\prime \prime}$ & 41 & lower reach & permanent & 12.00 \\
\hline 15 & $\begin{array}{l}\text { Krka River NP, Roški Slap } \\
\text { waterfall }\end{array}$ & $\mathrm{N} 43^{\circ} 54^{\prime} 20.00^{\prime \prime}$ & $\mathrm{E} 15^{\circ} 58^{\prime} 22.00^{\prime \prime}$ & 55 & lower reach & permanent & 13.00 \\
\hline 16 & Gacka River, Tonkovića spring & $\mathrm{N} 44^{\circ} 47^{\prime} 17.35^{\prime \prime}$ & $\mathrm{E} 15^{\circ} 22^{\prime} 01.66^{\prime \prime}$ & 465 & $\begin{array}{l}\text { limnocrene } \\
\text { spring }\end{array}$ & permanent & 9.50 \\
\hline 17 & Gacka River, Majer spring & $\mathrm{N} 44^{\circ} 48^{\prime} 51.52^{\prime \prime}$ & $\mathrm{E} 15^{\circ} 21^{\prime} 31.46^{\prime \prime}$ & 459 & $\begin{array}{l}\text { limnocrene } \\
\text { spring }\end{array}$ & permanent & 9.00 \\
\hline 18 & Zrmanja River, spring & $\mathrm{N} 44^{\circ} 12^{\prime} 18.13^{\prime \prime}$ & $\mathrm{E} 16^{\circ} 05^{\prime} 05.21^{\prime \prime}$ & 280 & rheocrene spring & permanent & 9.00 \\
\hline 19 & Ljuta River, Konaovski dvori & $\mathrm{N} 42^{\circ} 32^{\prime} 16.41^{\prime \prime}$ & $\mathrm{E} 18^{\circ} 22^{\prime} 43.59^{\prime \prime}$ & 80 & upper reach & permanent & 8.5 \\
\hline 20 & Ljuta River, spring & $\mathrm{N} 42^{\circ} 32^{\prime} 11.00^{\prime \prime}$ & $\mathrm{E} 18^{\circ} 22^{\prime} 41.00^{\prime \prime}$ & 70 & rheocrene spring & permanent & 11.50 \\
\hline 21 & Jadro River, spring & $\mathrm{N} 43^{\circ} 32^{\prime} 30.30^{\prime \prime}$ & $\mathrm{E} 16^{\circ} 31^{\prime} 11.80^{\prime \prime}$ & 35 & $\begin{array}{l}\text { limnocrene } \\
\text { spring }\end{array}$ & permanent & 12.00 \\
\hline 22 & Žrnovnica River, spring & $\mathrm{N} 43^{\circ} 31^{\prime} 22.13^{\prime \prime}$ & $\mathrm{E} 16^{\circ} 34^{\prime} 25.95^{\prime \prime}$ & 70 & rheocrene spring & permanent & 12.00 \\
\hline 23 & Krčić River, spring & $\mathrm{N} 44^{\circ} 01^{\prime} 31.45^{\prime \prime}$ & $\mathrm{E} 16^{\circ} 19^{\prime} 52.71^{\prime \prime}$ & 370 & rheocrene spring & temporary & 9.00 \\
\hline 24 & Norin River, Prud spring & $\mathrm{N} 43^{\circ} 05^{\prime} 41.44^{\prime \prime}$ & $\mathrm{E} 17^{\circ} 37^{\prime} 12.24^{\prime \prime}$ & 3 & $\begin{array}{l}\text { limnocrene } \\
\text { spring }\end{array}$ & permanent & 13.50 \\
\hline 25 & Kupa River, spring brook & $\mathrm{N} 45^{\circ} 29^{\prime} 26.75^{\prime \prime}$ & $\mathrm{E} 14^{\circ} 41^{\prime} 26.47^{\prime \prime}$ & 385 & $\begin{array}{l}\text { limnocrene } \\
\text { spring }\end{array}$ & permanent & 7.50 \\
\hline 26 & Una River, spring & $\mathrm{N} 44^{\circ} 23^{\prime} 58.01^{\prime \prime}$ & $\mathrm{E} 16^{\circ} 06^{\prime} 13.93^{\prime \prime}$ & 396 & $\begin{array}{l}\text { limnocrene } \\
\text { spring }\end{array}$ & permanent & 10.00 \\
\hline 27 & Čabranka River, spring & $\mathrm{N} 43^{\circ} 47^{\prime} 50.69^{\prime \prime}$ & $\mathrm{E} 16^{\circ} 19^{\prime} 26.43^{\prime \prime}$ & 570 & rheocrene spring & permanent & 8.00 \\
\hline 28 & Krupa River, spring & $\mathrm{N} 44^{\circ} 11^{\prime} 48.38^{\prime \prime}$ & $\mathrm{E} 15^{\circ} 54^{\prime} 32.45^{\prime \prime}$ & 1058 & rheocrene spring & permanent & 10.00 \\
\hline 29 & Kamačnik River, spring & $\mathrm{N} 45^{\circ} 21^{\prime} 38.45^{\prime \prime}$ & $\mathrm{E} 15^{\circ} 03^{\prime} 59.77^{\prime \prime}$ & 483 & $\begin{array}{l}\text { limnocrene } \\
\text { spring }\end{array}$ & permanent & 8.00 \\
\hline 30 & Rječina River, spring & $\mathrm{N} 45^{\circ} 24^{\prime} 31.30^{\prime \prime}$ & $\mathrm{E} 14^{\circ} 25^{\prime} 30.01^{\prime \prime}$ & 370 & rheocrene spring & permanent & 8.00 \\
\hline 31 & Kosovčica River, spring & $\mathrm{N} 43^{\circ} 56^{\prime} 28.00^{\prime \prime}$ & $\mathrm{E} 16^{\circ} 15^{\prime} 10.00^{\prime \prime}$ & 260 & $\begin{array}{l}\text { limnocrene } \\
\text { spring }\end{array}$ & permanent & 9.00 \\
\hline 32 & $\begin{array}{l}\text { Curak Stream, after HP } \\
\text { Munjara }\end{array}$ & $\mathrm{N} 45^{\circ} 25^{\prime} 38.12^{\prime \prime}$ & $\mathrm{E} 14^{\circ} 53^{\prime} 34.45^{\prime \prime}$ & 339 & lower reach & permanent & 8.00 \\
\hline 33 & Bistrica Spring, Dobra River & $\mathrm{N} 45^{\circ} 16^{\prime} 27.80^{\prime \prime}$ & $\mathrm{E} 15^{\circ} 17^{\prime} 28.10^{\prime \prime}$ & 230 & rheocrene spring & permanent & 10.50 \\
\hline 34 & Ribnjak Spring, Dobra River & $\mathrm{N} 45^{\circ} 20^{\prime} 05.00^{\prime \prime}$ & $\mathrm{E} 15^{\circ} 15^{\prime} 07.00^{\prime \prime}$ & 260 & rheocrene spring & permanent & 10.00 \\
\hline 35 & Podumol Spring, Dobra River & $\mathrm{N} 45^{\circ} 21^{\prime} 27.3^{\prime \prime}$ & $\mathrm{E} 15^{\circ} 18^{\prime} 31.20^{\prime \prime}$ & 184 & $\begin{array}{l}\text { limnocrene } \\
\text { spring }\end{array}$ & permanent & 10.50 \\
\hline \multirow[t]{2}{*}{36} & Kupica River, spring & $\mathrm{N} 45^{\circ} 25^{\prime} 47.34^{\prime \prime}$ & $\mathrm{E} 14^{\circ} 51^{\prime} 11.96^{\prime \prime}$ & 310 & $\begin{array}{l}\text { limnocrene } \\
\text { spring }\end{array}$ & permanent & 7.50 \\
\hline & $\begin{array}{l}\text { BOSNIA AND } \\
\text { HERZEGOVINA }\end{array}$ & & & & & & \\
\hline 37 & Bistrica River, spring & $\mathrm{N} 43^{\circ} 49^{\prime} 55.76^{\prime \prime}$ & $\mathrm{E} 17^{\circ} 00^{\prime} 31.21^{\prime \prime}$ & 777 & rheocrene spring & permanent & 8.00 \\
\hline 38 & Sturba River, spring & $\mathrm{N} 43^{\circ} 46^{\prime} 26.18^{\prime \prime}$ & $\mathrm{E} 17^{\circ} 01^{\prime} 24.43^{\prime \prime}$ & 753 & rheocrene spring & permanent & 8.00 \\
\hline 39 & Miljacka River, spring & $\mathrm{N} 43^{\circ} 47^{\prime} 07.00^{\prime \prime}$ & $\mathrm{E} 18^{\circ} 34^{\prime} 25.00^{\prime \prime}$ & 1026 & rheocrene spring & permanent & 6.50 \\
\hline 40 & $\begin{array}{l}\text { Lištica River, spring } \\
\text { REPUBLIC OF NORTH } \\
\text { MACEDONIA }\end{array}$ & $\mathrm{N} 43^{\circ} 23^{\prime} 46.87^{\prime \prime}$ & $\mathrm{E} 17^{\circ} 35^{\prime} 50.23^{\prime \prime}$ & 322 & rheocrene spring & permanent & 8.00 \\
\hline 41 & $\begin{array}{l}\text { Lazaropole, Hygropetric } \\
\text { beside the road }\end{array}$ & $\mathrm{N} 41^{\circ} 33^{\prime} 38.10^{\prime \prime}$ & $\mathrm{E} 20^{\circ} 41^{\prime} 39.00^{\prime \prime}$ & 916 & rheocrene spring & permanent & 8.00 \\
\hline 42 & Galička River, spring & $\mathrm{N} 41^{\circ} 35^{\prime} 36.40^{\prime \prime}$ & $\mathrm{E} 20^{\circ} 39^{\prime} 52.30^{\prime \prime}$ & 1407 & rheocrene spring & permanent & 5.00 \\
\hline 43 & Vevčani Springs & $\mathrm{N} 41^{\circ} 14^{\prime} 22.50^{\prime \prime}$ & $\mathrm{E} 20^{\circ} 35^{\prime} 03.70^{\prime \prime}$ & 951 & rheocrene spring & permanent & 8.00 \\
\hline 44 & $\begin{array}{l}\text { Rosočka River, Rosoki spring } \\
\text { MONTENEGRO }\end{array}$ & $\mathrm{N} 41^{\circ} 34^{\prime} 10.00^{\prime \prime}$ & $\mathrm{E} 20^{\circ} 41^{\prime} 35.90^{\prime \prime}$ & 1024 & rheocrene spring & permanent & 7.00 \\
\hline 45 & Alipaša Springs, Gusinje & $\mathrm{N} 42^{\circ} 33^{\prime} 00.50^{\prime \prime}$ & $\mathrm{E} 19^{\circ} 49^{\prime} 33.10^{\prime \prime}$ & 932 & helocrene spring & permanent & 6.00 \\
\hline 46 & Ibra River, spring & $\mathrm{N} 42^{\circ} 47^{\prime} 51.00^{\prime \prime}$ & $\mathrm{E} 20^{\circ} 05^{\prime} 25.30^{\prime \prime}$ & 1256 & rheocrene spring & permanent & 5.00 \\
\hline
\end{tabular}




\subsection{Sampling and Data Collection}

For this study, we examined all data from the literature, environmental impact studies and baseline studies [53-55], as well as field sampling conducted throughout the western part of Southeastern Europe, where E. bosnica has been recorded in the period of the last 15 years (from 2004 to 2019). Sampling of water beetles was carried out in karst springs and rivers in Croatia (CRO), Bosnia and Herzegovina (B\&H), Montenegro (MG) and the Republic of North Macedonia (RNM) (Table 1 and Figure 2). Most of these sites are located in the area of the Dinaric Karst. Comprehensive studies in Croatia (Cetina River and Plitvice Lakes) are also included $[14,16,55]$, as well as the unpublished study on water beetles in the Spring of the Bistrica River (B\&H), where the species was extremely abundant [56]. The water beetles at the latter locality site were sampled monthly $(2007 / 2008)$ in three types of microhabitats: bryophytes (three microhabitats), sand and gravel (one microhabitat), and pebbles (one microhabitat), using the methodology following Mičetić Stanković et al. [14, 16].

The typology of springs used in this study follows Hynes [57], who distinguishes three basic types: limnocrene, rheocrene and helocrene spring. All habitats were analyzed in terms of elevation, canopy cover and permanence of water flow. The mean annual water temperature of the sites was determined by using unpublished data from field sampling, various works from the literature and data from state hydrological institutes, and then analyzed in relation to the following factors: (1) position of the habitat in the watercourse (spring, upper, middle or lower reach), (2) elevation of the habitat (the range was defined as follows: $<200 \mathrm{~m} ; 200-500 \mathrm{~m} ;>500 \mathrm{~m}$ ) and (3) canopy coverage (3 categories: open canopy, open/closed (20-50\% of the watercourse in shade), and closed ( $>50 \%$ of the watercourse in shade)).

Species was identified by using Berthélemy [58] and specimens in the World Water Beetle Collection and Research Centre of the Natural History Museum in Vienna. Identification based on the male genitalia structure, the aedeagus, was conducted by an Olympus ZX9 stereomicroscope at 40-60× magnification. The aedeagus was placed in liquid medium, examined and afterward glued together with dry mounted habitus. The habitus was photographed with the Olympus microscope BX 51, while the male genitalia were photographed with a Carl Zeiss Axio Vert inverted microscope.

All specimens of E. bosnica collected in this study were deposited in the Croatian Natural History Museum, Zagreb.

\subsection{Data Analysis}

Species traits both from published and unpublished data were analyzed, compiled and reviewed in terms of (1) population traits, i.e., seasonal dynamics, adult/larvae ratio, sex ratio; and (2) ecological traits, i.e., preference for abiotic and biotic environmental factors.

In addition to the published data on population traits of the species $[14,16]$, we conducted an analysis by using the unpublished data collected in the Spring of the Bistrica River (B\&H). The non-parametric Friedman's Test and General Linear Model (GLM) were used to test for differences in the abundance of life stages as a function of season and substrate type. Prior to the analysis, biological data were log-transformed. Seasons were defined as follows: spring, March to May; summer, June to August; autumn, September to November; winter, December to February.

Data for sex ratio were collected from four springs and their accompanying sites (for details on site and substrate, see Mičetić Stanković et al. [14,16,56]), where E. bosnica was the only species of the genus Elmis. Variation in sex ratio due to substrate type and season was tested by using a General Linear Model. Prior to the analysis, biological data were log-transformed.

Ecological traits of species were represented as preference for a particular environmental factor. In addition to published data $[14,16]$, we also included unpublished data from the Spring of the Bistrica River (B\&H). In the latter study site, the relationship between species and environmental factors in spring was analyzed by using Pearson's correlation 
coefficient (r). The correlation was performed separately for adults and larvae based on their abundances. For all measured variables (Figure 3; see also Refs. [14,16]), in the Spring of the Bistrica River, a preselection was carried out prior to the principal component analysis (PCA). Thus, the variables were tested with stepwise regression (interactive-forward selection) to determine which variables significantly influence both the larval and adult stages. Principal components analysis (PCA) was used to evaluate the potential influence of eleven variables on species abundance [59]. Prior to PCA analysis, the abiotic data were normalized, while the biological data were log-transformed.
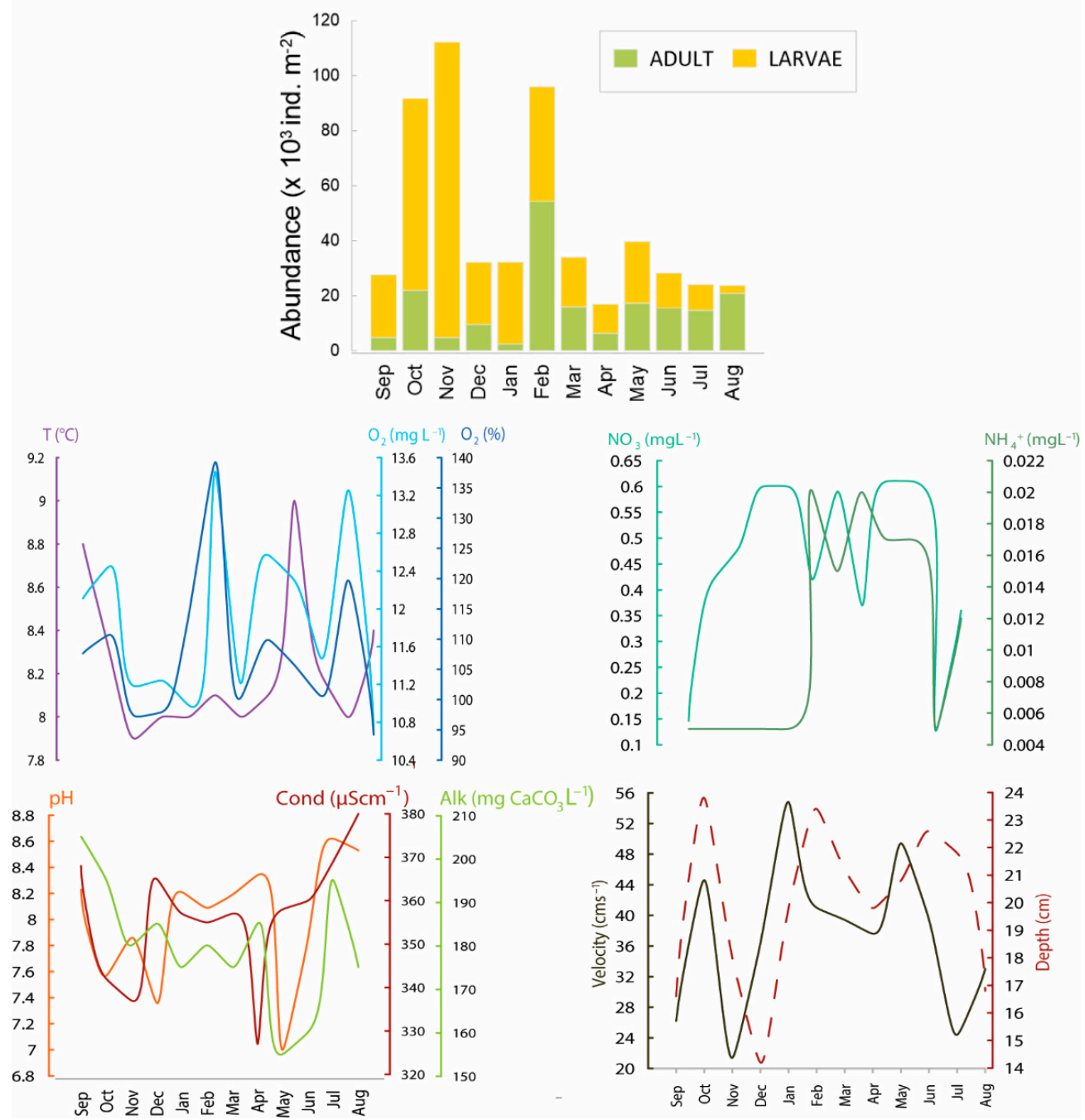

Figure 3. Environmental characteristics and seasonal dynamics of E. bosnica (Zaitzev, 1908), in the Spring of the Bistrica River, Bosnia and Herzegovina. Abbreviations: $\mathrm{T}\left({ }^{\circ} \mathrm{C}\right)$, water temperature; $\mathrm{O}_{2}\left(\mathrm{mg} \mathrm{L}^{-1}\right)$, dissolved oxygen; $\mathrm{O}_{2}(\%)$, oxygen saturation; Cond $\left(\mu \mathrm{S} \mathrm{cm}{ }^{-1}\right)$, conductivity; Alk $\left(\mathrm{mg} \mathrm{CaCO} \mathrm{L}^{-1}\right)$, alkalinity; $\mathrm{NO}_{3}\left(\mathrm{mg} \mathrm{L}^{-1}\right)$, nitrates; $\mathrm{NH}_{4}{ }^{+}\left(\mathrm{mg} \mathrm{L}^{-1}\right)$, ammonium ions.

All analyses were performed by using the software package SPSS 17.0 [60] and PRIMER v.6 [61] for Windows. The graphics were created with Adobe ${ }^{\circledR}$ Illustrator ${ }^{\circledR}$ CS6 and Grapher ${ }^{\mathrm{TM}} 11$ from Golden Software, LLC [62].

\subsection{DNA Extraction, PCR Amplification, Sequencing and Analyses}

Before genomic DNA extraction, beetle specimens were briefly soaked in sterile Milli$\mathrm{Q}$ water and air-dried for fifteen minutes. Non-destructive genomic DNA extraction from entire specimens was carried out by using the GenEluteTM Mammalian Genomic DNA Miniprep Kit (Sigma-Aldrich, St. Louis, MO, USA), following the protocol for rodent tail 
preparation, but with slight modifications (incubation in Proteinase K overnight; final DNA elution in $100 \mu \mathrm{L}$ of elution solution). After DNA extraction, specimens were briefly rinsed in Milli-Q water, transferred to ethanol and stored as vouchers (listed in Table 2).

Table 2. Specimens of E. bosnica (Zaitzev, 1908) DNA, barcoded in this study.

\begin{tabular}{lllcc}
\hline \multicolumn{1}{c}{ Sample } & \multicolumn{1}{c}{ Sampling Site } & \multicolumn{1}{c}{ BOLD-ID } & GenBank Accession No. & Voucher \\
\hline VMS-B14 & Plitvica River NP (CRO) & CROBF009-19 & OL874461 & CROBB9 \\
VMS-B61 & Žrnovnica River, spring (CRO) & CROBF010-19 & OL874463 & CROBB10 \\
VMS-B30 & Žrnovnica River, spring (CRO) & CROBF006-19 & OL874460 & CROBB6 \\
VMS-B102 & Kupica River, spring (CRO) & CROBF008-19 & OL874462 & CROBB8 \\
EB144-MK & Galička River, spring (RNM) & CROEL024-21 & OL874459 & CROBB879 \\
\hline
\end{tabular}

The standard barcoding region of the mitochondrial COI gene [40] was amplified with the universal primers LCO1490/HCO2198 [63]. Amplification mixtures consisted of $1 \times$ DreamTaq $^{\mathrm{TM}}$ reaction buffer containing $2 \mathrm{mM} \mathrm{MgCl} \mathrm{m}_{2}$ (Thermo Fischer Scientific, Waltham, MA, USA), $0.2 \mathrm{mM}$ dNTP mix (Qiagen, Hilden, Germany), $0.5 \mu \mathrm{M}$ each primer, 1.0 U DreamTaq polymerase (Thermo Fischer Scientific, Waltham, MA, USA) and $3 \mu \mathrm{L}$ of DNA in a $20 \mu \mathrm{L}$ reaction volume. PCR products were enzymatically purified by using an ExoI-rSAP system (NEB, Ipswich, MA, USA), following the manufacturer's protocol, and bidirectionally sequenced in Macrogen Inc. (Amsterdam, The Netherlands), using amplification primers.

Sequences were checked and edited in Geneious 8.1.4. [64] and subsequently deposited in the NCBI and BOLD databases (NCBI and BOLD accession numbers are listed in Table 2 and available in the BOLD project CROEL). Barcode Index Numbers (BINs) were assigned to specimens by using the REfined Single Linkage Analysis (RESL) algorithm in BOLD [46].

BOLD identification tool [65] was used to compare the DNA barcode sequences amplified from our samples with the public barcode data available in the BOLD database. The NCBI GenBank database was searched by using the BLAST tool via the megablast algorithm. Available COI sequences of Elmidae specimens (genus Elmis and outgroups) were withdrawn from the BOLD public records database and used for subsequent analyses.

The multiple sequence alignment was constructed with MAFFT version 7, using the "Auto" strategy (see Refs. [66,67]; the final alignment is available upon request). Intraspecific and interspecific p-distances were calculated by using MEGA 7.0.25. [68]. The maximum likelihood (ML) tree was constructed on the PhyML 3.0 webserver [69,70], with automatic model selection by SMS (determined by the AIC selection criterion) [71] and aLRT SH-like support [72]. The resulting tree was edited in FigTree v.1.4.3. [73].

\section{Results and Discussion}

\subsection{Identification and Distribution}

During field trips throughout Southeastern Europe over a 15-year period (from 2004 to 2019), the species was recorded at a total of 46 sites (Figure 2 and Table 1). The identification of the species was based on the morphology of the male genitalia, which differs considerably from other Elmis species that might occur there [7,74]. The penis of E. bosnica is noticeably larger than the associated parameres (Figure 4). Specimens collected from four localities (springs of Plitvice Lakes NP, Žrnovnica River and Kupica River (CRO) and spring of the Galička River (RNM) - listed in Table 2) were further DNA barcoded. BLAST search resulted in best hits with the samples of Elmis aenea and Elmis rioloides (Kuwert, 1890) (93-94\% identity on average), while the BOLD identification tool could not give a specieslevel match in a database of public records; in accordance with that, BIN-RESL assigned a new BIN to sequences of E. bosnica (BIN no. BOLD: ADR7537). The average intraspecific variability (p-distance) between the sequences of E. bosnica amounts to $0.3 \%$ (range 0.0 $1.7 \%$ ), while the interspecific divergence with respect to other Elmis species ranges from 6.2 to $15.8 \%$. These values are comparable to intraspecific vs. interspecific distances for the 
barcoding region observed in Coleoptera [41,75]. However, the relatively high variability of the specimen from the Spring of the Galička River, RNM (COI p-distance of $1.7 \%$ with respect to other specimens of E. bosnica), may indicate the existence of the significant genetic differentiation within this species and prompts for more comprehensive analyses. It is noteworthy that Oláh et al. [76] have already identified new caddisfly species in this highaltitude spring isolated at $1407 \mathrm{~m}$ a.s.l., and it may potentially hide taxonomically interesting fauna. The phylogenetic ML tree based on COI sequences (Figure 5 and Supplementary Materials File S1) confirms that E. bosnica forms a monophyletic group most closely related to the sequences of E. rioloides and E. aenea. The three species are traditionally considered to be close relatives [58], so this result supports this notion. However, keeping in mind the limitations of the use of single molecular marker, phylogenetic relationships within this genus should be analyzed with an expanded molecular dataset and more comprehensive sampling covering the species' distribution ranges.

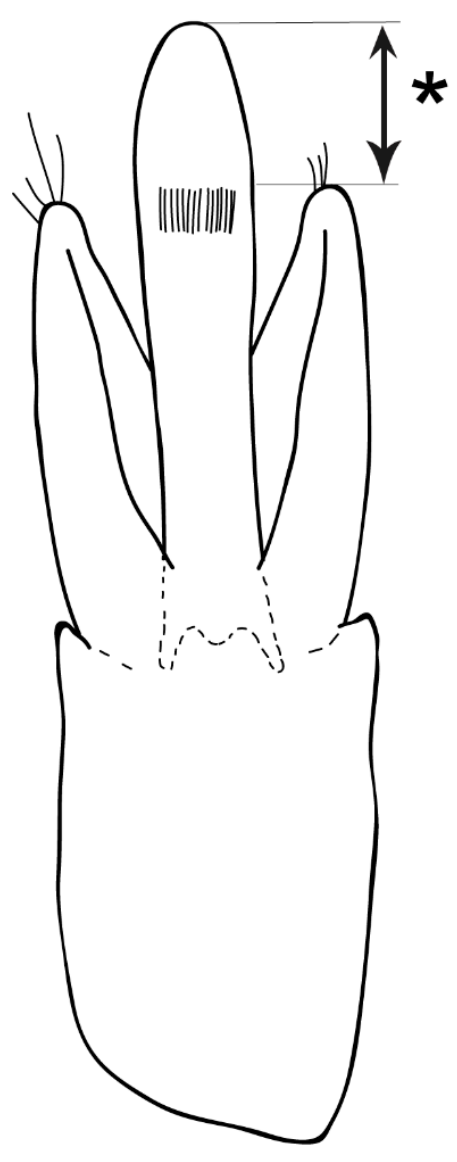

Elmis bosnica

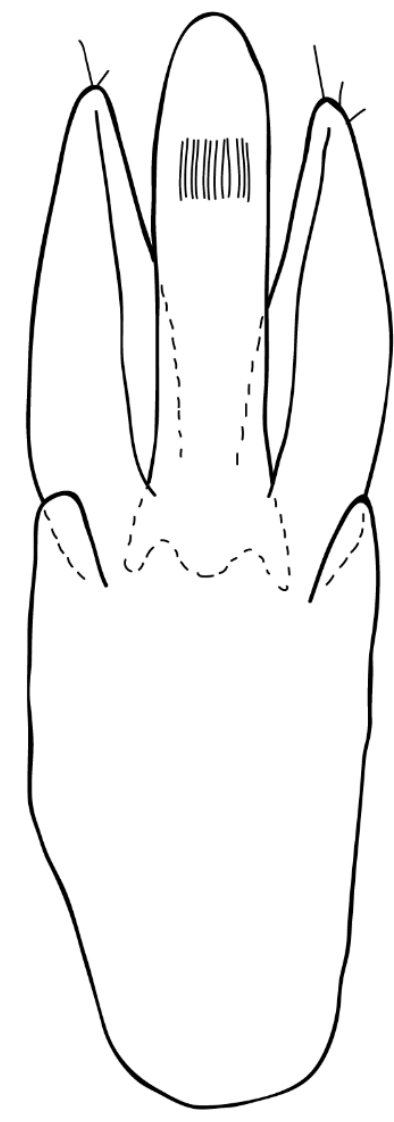

Elmis aenea

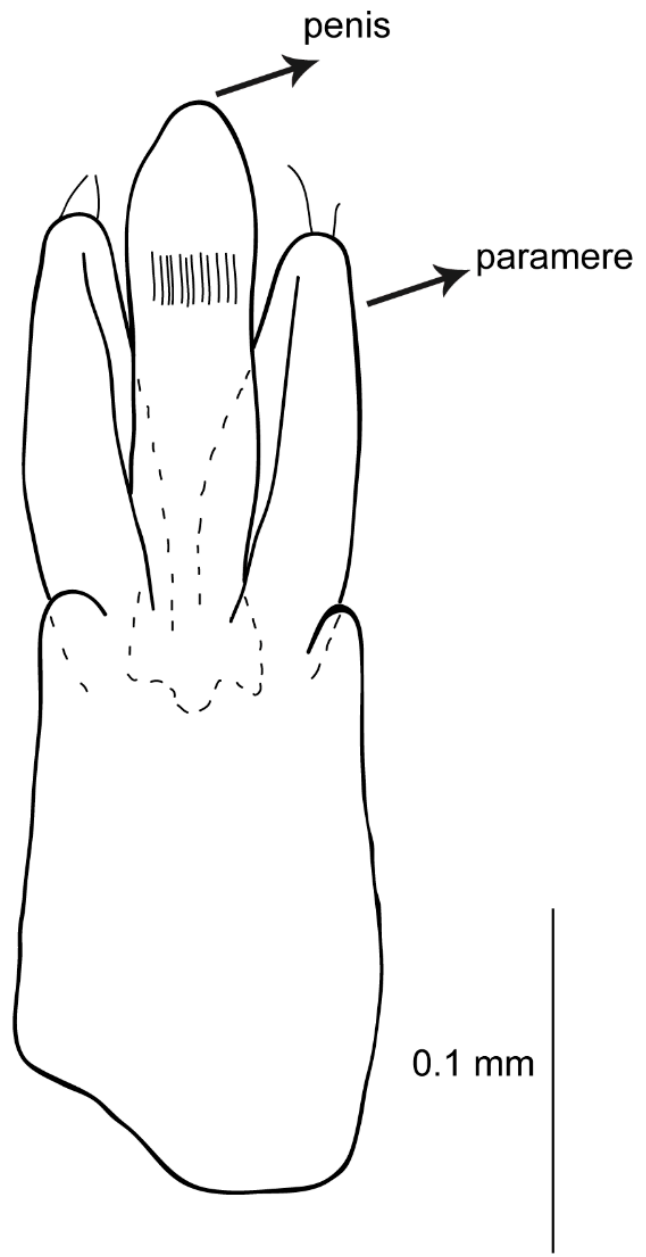

Elmis rioloides

Figure 4. Drawing of the male genitalia of E. bosnica and two other species occurring in the same habitat in Southeastern Europe. * Distance from the tip of the paramere to the tip of the penis as the main identification character. The drawing of the male genitalia of E. aenea and E. rioloides was adapted from Olmi [74]. 


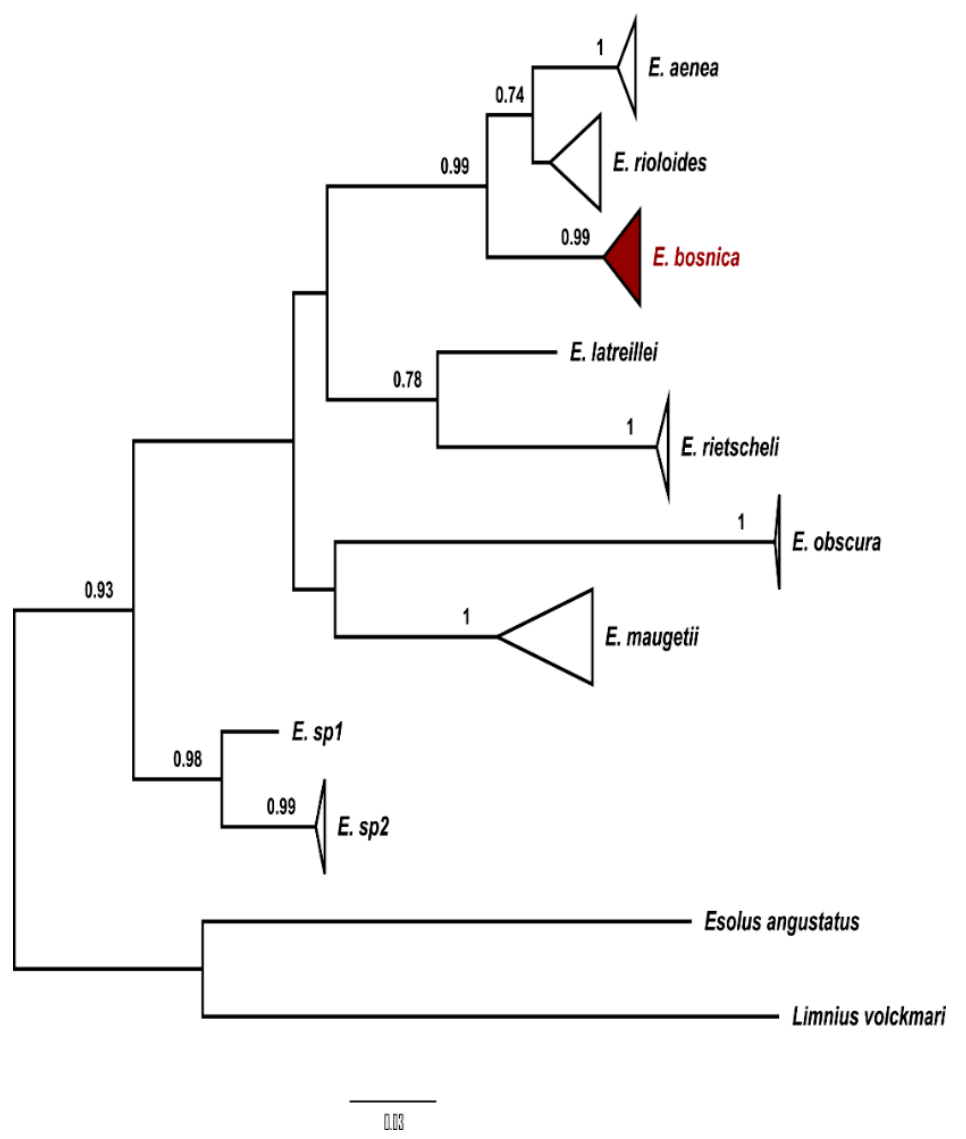

Figure 5. Maximum likelihood phylogenetic tree based on sequences of COI barcoding fragment of Elmis species publicly available in BOLD. Species clades are collapsed for simplicity; aLRT values are indicated on the nodes (values lower than 0.7 are not shown).

In the checklist of Croatian Elmidae, the habitats of E. bosnica are defined as springs; streams; and upper, middle and lower reaches of large and small karst Mediterranean and mountainous and submountainous rivers [13]. Although the number of localities included in this study is much higher than the one in the checklist, the type of habitat remains the same. The species is mainly recorded in karst springs and upper sections of rivers and streams. More so, as it is the only Elmis species there, especially in spring areas, it can be defined as a good indicator of stream zonation (see Refs. [14,16]). This is in complete contrast to the fauna of springs in the rest of Europe, where other species dominate, such as E. rietscheli Steffan, 1958; E. aenea; or E. latreillei Bedel, 1878 (e.g., see Refs. [77-79]). Zollhofer [80] hypothesized that the exclusive presence of crenal fauna in the springs is a result of competitive exclusion. Nevertheless, E. bosnica is also found in middle and lower sections of rivers, but only if the riverbed is a canyon type with fast-flowing oligotrophic and cold water. In these sections, the species cohabits with two other elmids, E. aenea and E. rioloides, which assemble typical crenal fauna in other parts of Europe $[6,8,10,14,16]$. Therefore, E. bosnica can be defined as crenophilic rather than a crenobiont species [81], as it reaches its maximum densities in spring areas $[14,16,56]$, but can also inhabit downstream habitats. It is important to address that we still do not know the northern distribution border of E. bosnica in Southeastern Europe, as the species has not yet been recorded in, for example, non-karst springs in northern parts of Croatia [82].

The range between the highest and the lowest altitude of the sampling site extended for $1404 \mathrm{~m}$ ( $\max =1407 \mathrm{~m}$ a.s.l., spring of the Galička River, RNM; and $\min =3 \mathrm{~m}$ a.s.l., spring of the Norin River in the village Prud, CRO). Three elevation ranges with significant differences in the mean water temperature were defined $(p=0.001, p \leq 0.001)$ (Table 1 and Figure 6). Overall, the mean annual water temperature of the habitats studied ranged 
from 5 to $13{ }^{\circ} \mathrm{C}$, so E. bosnica can be considered a typical inhabitant of spring with cold water $[27,29,31]$. Temperatures also differed between habitats, due to canopy cover and spring type, but without statistical confidence (Figure 6).

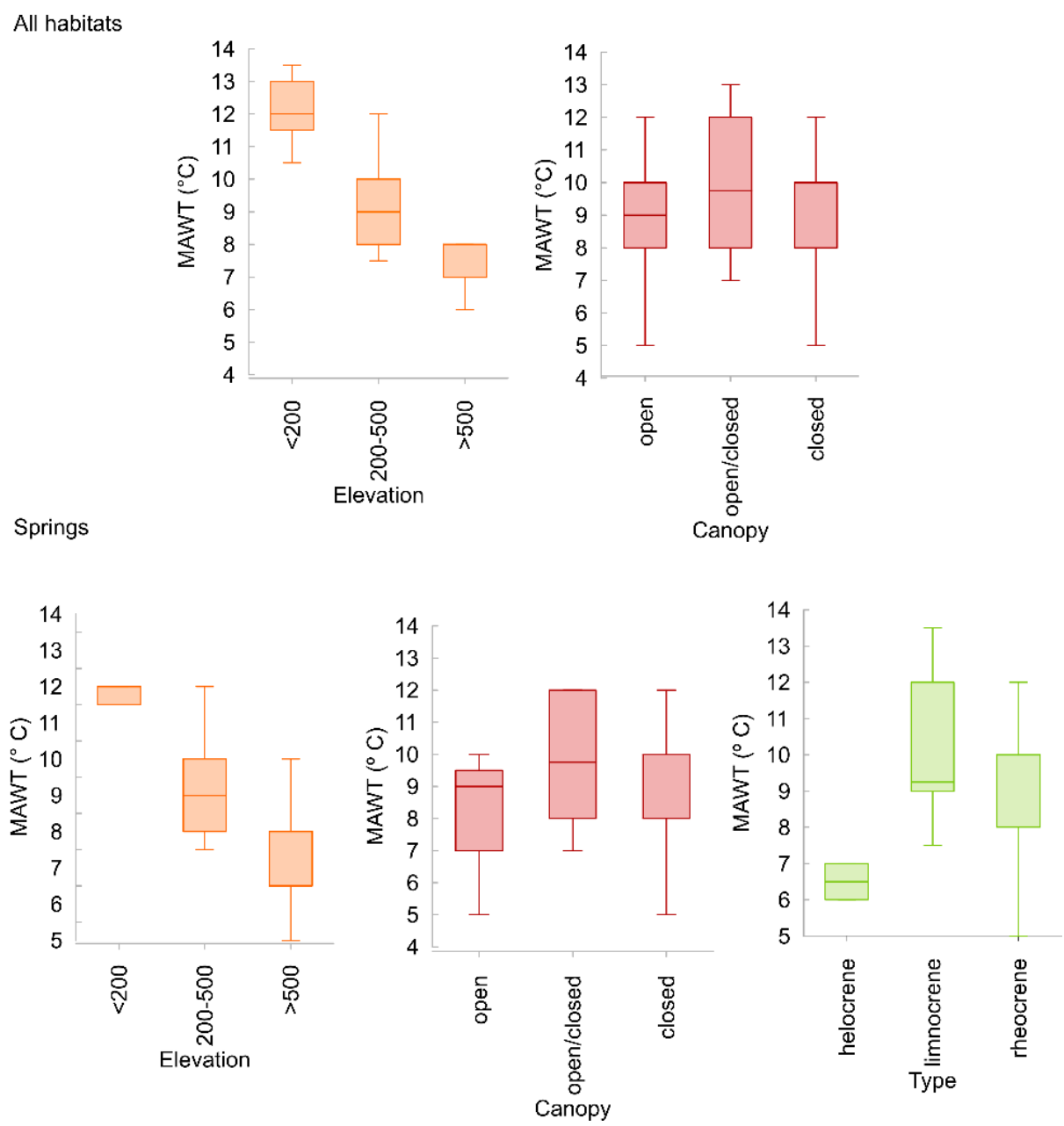

Figure 6. Differences in mean annual water temperature (MAWT) at sampled sites due to elevation, canopy cover and habitat type.

\subsection{Population Traits and Seasonal Dynamics}

Over the last 15 years, we have found large differences in the abundances of E. bosnica at spatial and temporal scales, especially when comparing study sites where the same methodology was applied. For example, in the Spring of the Bistrica River (B\&H), a total of 880,152 specimens per $\mathrm{m}^{2}$ were collected within one year, while in Spring of the Cetina River (CRO), only 110 specimens per $\mathrm{m}^{2}$ were identified [16]. Species abundance differed on a spatial scale in the Spring of the Bistrica River $(p=0.003, p<0.05)$, confirming that substrate type plays a key role in determining water beetle populations [83,84]. The abundance of $E$. bosnica also varied on a temporal scale (Figure 7) $(p=0.001, p<0.05$, Monte Carlo post hoc $p=0.001, p<0.05)$, a finding that is in agreement with previous results [12,14]. When life stages were analyzed separately, larvae showed large differences on an annual basis $(p=0$. 042, $p<0.05$ ). Berthélemy and de Riols [85] and Eliott [86] indicated an overlap of life stages of elmids during a one-year cycle, as was also confirmed for E. bosnica both in the Spring of the Bistrica River $(\mathrm{B} \& \mathrm{H})$ and at other study sites $[14,16]$. Latter studies have shown that the species adapts its life cycle to the characteristics of its habitat. Therefore, adults dominate in spring and especially in summer, regardless of environmental conditions. On the other hand, the seasonal dynamics of the larval stage are strongly dependent on the habitat, especially the density of the tree canopy, the permanence of the flow and the presence of 
bryophytes $[14,16,87]$. Thus, larvae are dominant in the cold months (autumn and winter) only if the habitats offer optimal conditions (e.g., open canopy and bryophytes), as was the case in the Spring of the Bistrica River. If, on the other hand, conditions are not favorable all year round, e.g., due to closed canopy cover or high differences in water flow, larvae dominate only in the warm months (spring and summer) and may even be absent in winter (see Refs. [14,16] for more information).

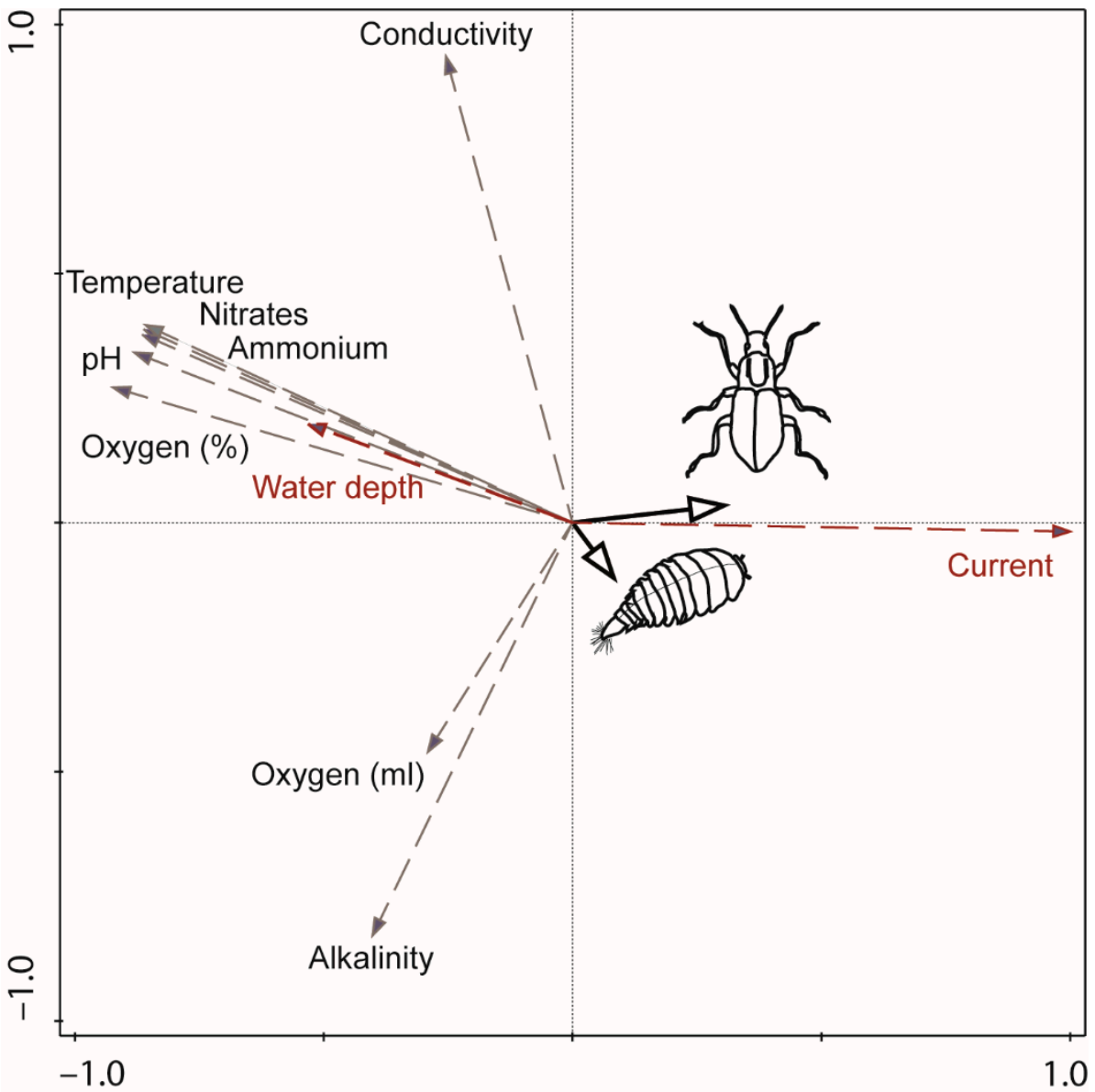

Figure 7. PCA ordination plot of E. bosnica (Zaitzev, 1908), and environmental variables in the Spring of the Bistrica River, Bosnia and Herzegovina. Variables that significantly affect the species are marked in red. Dashed arrows represent variables, and solid arrows represent life stages.

Although the sex ratio is known as one of the key parameters for knowing the biology of any species, there are few data in the literature on Elmidae [86,88-90]. Sex ratios of $E$. bosnica in four studied karst springs differed at spatial and temporal scales (Table 3). The abundance of males and females differed between seasons ( $p=0.0023, p \leq 0.05$; Figure 8$)$, with females generally dominating in spring (March and April), while males dominated in autumn (October and November). It can be seen that, in individual months, males can be considerably more abundant than females, as was the case in the Spring of the Bijela rijeka River (CRO) (autumn and winter: $p=0.05, p \leq 0.05$, Figure 3), which is in accordance with the study by Seagle [90]. Substrate type also proved to be an important factor in determining differences between male and female abundances in the Spring of the Bijela rijeka River (CRO) $(p=0.001, p \leq 0.001)$ and upper reach of the Bijela rijeka River $(p=0.001$, $p \leq 0.001$ ), as shown in Figure 8. Elliot [86], in his study of four elmid species, found that the sex ratio was 1:1 according to Fisher's principle [91,92], a result that was also found for E. bosnica in the Spring of the Bistrica River. In the other springs and habitats studied, however, the ratio was in favor of males, especially in the winter months; this could be explained by the emergence of females in summer $[88,89]$. 
Table 3. Sex ratio of E. bosnica (Zaitzev, 1908), in four karst springs and two rivers from Southeastern Europe. Symbol: $:$ female, $0^{7}-$ male.

\begin{tabular}{|c|c|c|c|c|c|c|c|c|c|c|c|c|}
\hline Microhabitat/Month & & & & & & & & & & & & \\
\hline Plitvice Lakes NP, CRO & February & March & April & May & June & July & August & September & October & November & December & January \\
\hline Spring of the Crna rijeka River, bryophytes & only o $0^{7}$ & 0 & 0 & $0.67: 1$ & $0.93: 1$ & $0.87: 1$ & $1.46: 1$ & $0.8: 1$ & 1.07:1 & 0 & 1.11:1 & 0 \\
\hline Middle reach of the Crna rijeka River, bryophytes & $0.5: 1$ & 0 & only o $o^{x}$ & 1 & $3: 1$ & $2: 1$ & 1 & only 우 & $5: 1$ & 0 & only $o^{x}$ & $1.5: 1$ \\
\hline Spring of the Bijela rijeka River, bryophytes & $1.42: 1$ & 1 & $0.42: 1$ & $0.33: 1$ & $2.08: 1$ & $0.9: 1$ & 9:1 & only o $0^{7}$ & $1.67: 1$ & only 9 & $0.17: 1$ & only o $0^{x}$ \\
\hline Upper reach of the Bijela rijeka River, angiosperms & 0 & only + & 0 & 0 & 0 & only o $0^{7}$ & only o $0^{7}$ & only o $0^{7}$ & 0 & only $q$ & only o $0^{x}$ & only \\
\hline Upper reach of the Bijela rijeka River, bryophytes & $5: 1$ & $2.67: 1$ & $0.33: 1$ & $2.17: 1$ & only or & 1 & $2.17: 1$ & $1.75: 1$ & $0.67: 1$ & $0.4: 1$ & $2.5: 1$ & only $q$ \\
\hline \multicolumn{13}{|l|}{ Spring of the Cetina River, CRO } \\
\hline Angiosperms & 0 & 0 & 0 & 0 & 0 & 0 & 1 & only o $0^{7}$ & 0 & 0 & 0 & 0 \\
\hline Pebbles & 0 & only + & 0 & 0 & 0 & only + & 0 & 0 & 0 & 0 & 0 & 0 \\
\hline \multicolumn{13}{|l|}{ Spring of the Bistrica River, B\&H } \\
\hline Bryophytes main course & 1.3:1 & $0.74: 1$ & 0.78:1 & 0.99:1 & 0.93:1 & 1.84:1 & $1.02: 1$ & $1.24: 1$ & $0.62: 1$ & $1.47: 1$ & $1.76: 1$ & 0 \\
\hline Bryophytes side channel & $0.59: 1$ & $0.53: 1$ & $0.23: 1$ & $0.77: 1$ & $0.61: 1$ & $0.17: 1$ & $0.91: 1$ & $1.77: 1$ & $1.2: 1$ & 2 & only & $1.07: 1$ \\
\hline Bryophytes side course & $1.45: 1$ & $0.95: 1$ & $0.85: 1$ & $1.45: 1$ & $1.68: 1$ & $1.46: 1$ & $1.02: 1$ & $1.48: 1$ & $1.24: 1$ & 2 & 1.09:1 & 0 \\
\hline Pebbles main course & $1.16: 1$ & $1.28: 1$ & 1 & $0.5: 1$ & $3.5: 1$ & $0.83: 1$ & 0 & $0.31: 1$ & 0 & $1.44: 1$ & 1 & $1.5: 1$ \\
\hline Sand and gravel main course & $0.82: 1$ & $0.87: 1$ & $0.86: 1$ & $1.33: 1$ & $0.65: 1$ & $0.69: 1$ & $1.04: 1$ & $1.67: 1$ & $1.13: 1$ & $0.44: 1$ & 1 & $1.37: 1$ \\
\hline
\end{tabular}


a) Spring of the Bijela rijeka River

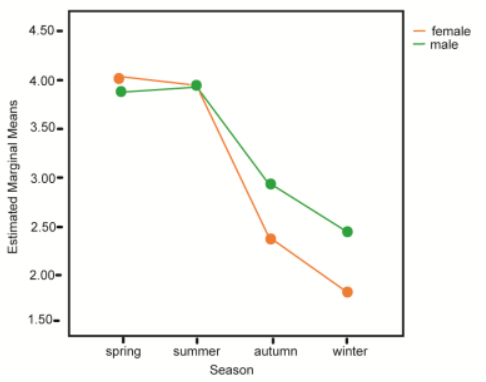

Upper reach of the Bijela rijeka River

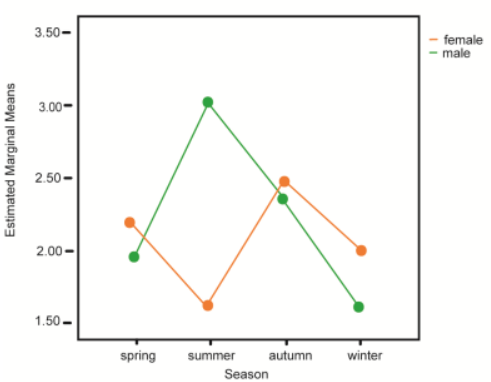

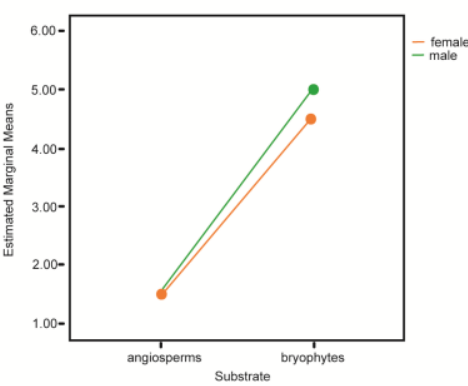

b) Spring of the Crna rijeka River

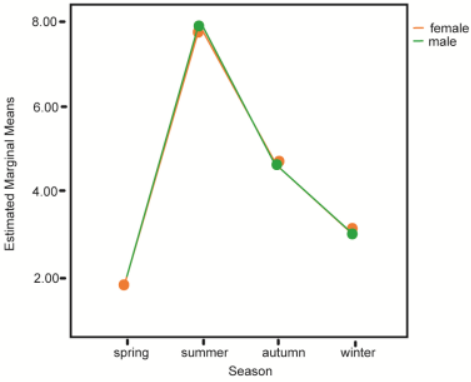

Middle reach of the Crna rijeka River
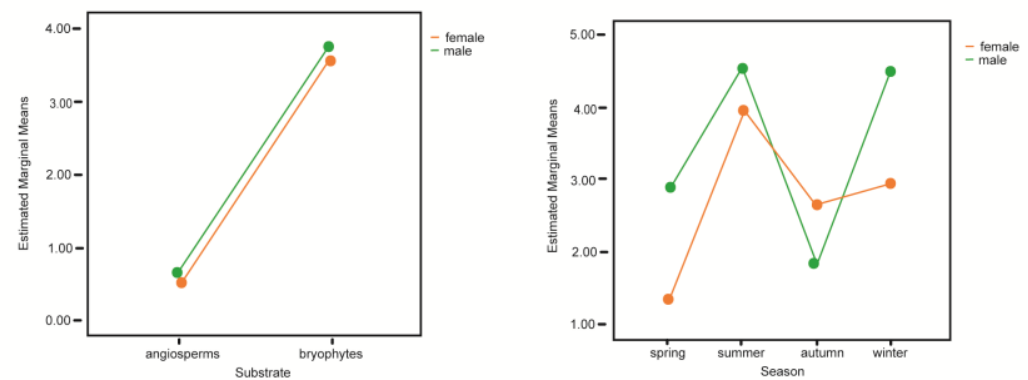

Figure 8. Univariate analysis profile plots of sex ratio of E. bosnica (Zaitzev, 1908), in two rivers in Croatia: (a) by season and substrate in the Bijela rijeka River and (b) by season in the Crna rijeka River.

\subsection{Ecological Traits}

The physicochemical parameters of the water in the Spring of the Bistrica River $(\mathrm{B} \& \mathrm{H})$ show the same karstic character of the water as those in which the species was previously recorded with oligotrophy and low temperature present $[14,16]$. In general, the assemblages of water beetles are primarily defined by substrate type, hydrogeology and current velocity $[83,84,93]$. Riffles with submerged aquatic vegetation, bryophytes or angiosperms are a particularly preferred substrate for elmid species, and also for $E$. bosnica $[14,16,20,56]$. The structure, type and distribution of aquatic vegetation determine both its abundance and distribution, especially in the adult stage [14], as bryophytes provide them with both food and shelter [8]. The bryophyte community of Cinclidotus aquaticus (Hedw.) Bruch et Schimp. and Platyhypnidium riparioides (Hedw.) Dixon. has already been defined as the preferred community for E. bosnica [14,16]. It was also confirmed in the Spring of the Bistrica River (B\&H), as the bryophyte community comprises these two species. Moreover, previous studies defined this bryophytes community joined with Elmis species as "the carrier of biodiversity" in freshwater karst habitats, but for misidentified E. maugetii (see Refs. $[13,21,22,94,95]$ for more information). Recent studies have shown that only E. bosnica occurs in these habitats, again indicating that this species was previously completely unknown and that further studies are needed $[13,14,56]$.

The relation to environmental factors differs between life stages of $E$. bosnica, as was determined both in previous studies $[14,16]$ and in the current study. The preselection analysis (interactive-forward selection) of all measured variables confirmed that water depth and current velocity are key factors in defining species abundance and distribution in the Spring of the Bistrica River. The adult stage correlated with both water depth and current velocity (depth: $\mathrm{r}=0.303, p<0.05$; velocity: $\mathrm{r}=-0.351, p<0.001$ ), while the larval stages correlated only with current velocity $(\mathrm{r}=-0.398, p<0.001)$. Afterward, a principal component analysis was conducted which indicated an eigenvalue of 0.780 , with a cumulative percentage of variance of $90.04 \%$ for the first two axes. Based on the ordination plot, the environmental variable that correlated most strongly with both life stages was current velocity. This result is consistent with the study by Brown [96], who hypothesized that riffle beetles seek out high currents to escape potential predators, particularly fish and birds. 
Flow permanence, conductivity and alkalinity are complementary but also important variables. Flow permanence defines distribution and composition of macroinvertebrates [97,98], especially in spring habitats ([81] and references therein). Hence, only one site in our study did not have permanent flow. In other habitats in Southeastern Europe, the $\mathrm{pH}$, oxygen saturation and alkalinity also proved to be relevant factors in determining the abundance and distribution of E. bosnica $[14,16,56]$. Therefore, we can only conclude that it is not possible to identify one or two main environmental factors that determine the populations of E. bosnica. On the contrary, the species can be used as an "environmental descriptor" due to its extreme sensitivity. In Plitvice Lakes NP (CRO), for example, the water has low nutrient variability and high alkalinity, and both factors have strongly influenced the abundance and distribution of E. bosnica $[14,56,99,100]$.

In order to better understand the ecology of species and the effects of anthropogenic pressures and even to take effective conservation procedures, further studies should focus on various biological traits, such as behavior, life history and physiology, or sex competition. However, these are still unknown to modern science, and we are only trying to interpret one piece of the puzzle based on snapshot surveys. An excellent attempt at a better understanding was made by Ortega et al. [101] (and references therein), who compared past assemblage data of water beetles with current data over an 18-year period. The study clearly shows that biological traits, rather than widespread environmental parameters, have the strongest effect in defining the current (and future) assemblage of the water beetle populations.

Based on the fact that water beetles, and even freshwater springs, are almost completely ignored from a conservation and protection point of view in Southeastern Europe, studies such as ours greatly improve the overall knowledge about endangered and specific habitats and their fauna. Even more, E. bosnica inhabits springs and cold, clear fresh waters also in the Mediterranean part of Europe, which is defined as a "biodiversity hotspot" but is under severe anthropogenic pressure $[4,5,102]$. This area is one of the richest in terms of total number of species and especially endemic species, so a higher proportional loss of species in absolute terms will lead to even greater losses [1]. Spring ecosystems in Southeastern Europe should be a top priority in conservation plans, similar to those in the Mediterranean [2].

\subsection{Conclusions and Outlook}

In conclusion, our study provides the first comprehensive review of all published and unpublished data, as well as the results of various projects and field sampling, in which E. bosnica has been studied. This species has been completely overlooked until recently, despite the fact that it is the only elmid species and often the dominant species in benthic communities of karst springs and lower sections of high-current waterbodies in Southeastern Europe. We expect that E. bosnica can no longer be misidentified due to the identification characteristics presented. The species has proven to be a useful environmental descriptor and can easily be used as a biological indicator due to its easy identification. The need for conservation stems from the fact that the species is remarkably sensitive to environmental conditions and secondly that it inhabits cold karst springs, habitats that are under increasing anthropogenic pressure [30] and disappearing at an alarming rate [29]. Therefore, only with permanent conservation programs can these unique habitats be protected for future generations, and then their fauna, including E. bosnica, will no longer be overlooked.

Supplementary Materials: The following supporting information can be downloaded at: https: / /www.mdpi.com/article/10.3390/d14010026/s1. Supplementary File S1: Elmis ML boot.

Author Contributions: V.M.S., field work, conceptualization, visualization and writing-review and editing; B.B.M., DNA and lab work and interpretation of molecular analysis; M.K., field work, review and supervision. All authors have read and agreed to the published version of the manuscript. 
Funding: This research was financed by the project "DNA barcoding of Croatian biodiversity" funded by Croatian Science Foundation, 2018-2021 (No. 06-2016-9988, PL: M. Kučinić); projects “Arthropod diversity and ecology of protected karst areas of Croatia", 2007-2012 (No. 119-1193080-1206, PL: M. Kučinić) and "Invertebrate taxonomy, ecology and biogeography of Croatian aquatic ecotones", 2007-2009 (No. 119-1193080-3076, PL: M. Kerovec), supported by the Croatian Ministry of Science, Education and Sports; project "The Drusinae (Insecta: Trichoptera) in a world of global change", funded by Austrian Science Foundation (FWF), Wien, 2012-2016 (No. P23687-B17, PL: Waringer J.); and "The MULTISEC project (MULTImetric System of Evaluating Crenobiocoenosis) study", 20132016, funded by The Environmental Protection and Energy Efficiency Fund (EPEEF) of Croatia (PL: S. Gottstein). The funders had no role in study design, data collection and analysis, decision to publish or preparation of the manuscript.

\section{Institutional Review Board Statement: Not applicable.}

Data Availability Statement: The original contributions presented in the study are publicly available. These data can be found in the Supplementary Materials.

Acknowledgments: We thank the Plitvice Lakes NP Authorities, the Krka River NP Authorities and the Mavrovo NP Authorities for permission to sample. We are very grateful to Vladimir Krpač (Institute of Ecology and Technology, Republic of North Macedonia); Vladimir Pešić (University of Montenegro, Montenegro); Svjetlana Stanić-Koštroman (University of Mostar, Bosnia and Herzegovina); and especially to the Rimac (Livno, Bosnia and Herzegovina) and Zima (Sturba, Bosnia and Herzegovina) families for their indispensable and kind help during field sampling. Many thanks to Manfred A. Jäch for the much-needed initial help at the beginning of the study of the wonderful world of water beetles. Special thanks to Vladimir Bartovsky (University of Zagreb, Croatia) for help with photographs of the specimen and aedeagus. We would like to thank Igor Stanković (Hrvatske vode, Croatia) for help with photographs of the specimen, help with the ArcGIS software and production of the map.

Conflicts of Interest: The authors declare no conflict of interest.

\section{References}

1. Newbold, T.; Oppenheimer, P.; Etard, A.; Williams, J.J. Tropical and Mediterranean biodiversity is disproportionately sensitive to land-use and climate change. Nat. Ecol. Evol. 2020, 4, 1630-1638. [CrossRef]

2. Fernández-Martínez, M.; Corbera, J.; Domene, X.; Sayol, F.; Sabater, F.; Preece, C. Nitrate pollution reduces bryophyte diversity in Mediterranean springs. Sci. Total Environ. 2020, 705, 135823. [CrossRef]

3. Bes, M.; Corbera, J.; Sayol, F.; Bagaria, G.; Jover, M.; Preece, C.; Viza, A.; Sabater, F.; Fernández-Martínez, M. On the influence of water conductivity, $\mathrm{pH}$ and climate on bryophyte assemblages in Catalan semi-natural springs. J. Bryol. 2018, 40, 149-158. [CrossRef]

4. Cantonati, M.; Füreder, L.; Gerecke, R.; Jüttner, I.; Cox, E.J. Crenic habitats, hotspots for freshwater biodiversity conservation: Toward an understanding of their ecology. Freshw. Sci. 2012, 31, 463-480. [CrossRef]

5. Pascual, R.; Nebra, A.; Gomà, J.; Pedrocchi, C.; Cadiach, O.; García, G.; Solé, J. First data on the biological richness of Mediterranean springs. Limnetica 2020, 39, 121-139. [CrossRef]

6. Jäch, M.A.; Balke, M. Global diversity of water beetles (Coleoptera) in freshwater. Hydrobiologia 2008, 595, 419-442. [CrossRef]

7. Jäch, M.A.; Kodada, J.; Brojer, M.; Shepard, W.D.; Čiampor, F. Coleoptera: Elmidae and Protelmidae, World Catalogue of Insects; Brill: Leiden, The Netherlands, 2016; Volume 14, p. 318.

8. Elliott, J.M. The ecology of riffle beetles (Coleoptera: Elmidae). Freshw. Rev. 2008, 1, 189-203. [CrossRef]

9. Jäch, M.A. Annotated check list of aquatic and riparian/littoral beetle families of the world. In Water Beetles of China; Jäch, M.A., Ji, L., Eds.; Zoologisch-Botanische Gesellschaft in Österreich und Wiener Koleopterologen Verein: Wien, Austria, 1998; pp. 25-42.

10. Moog, O.; Hartmann, A. Fauna Aquatica Austriaca, 3rd ed.; Federal Ministry of Agriculture, Forestry, Environment and Water Management: Wien, Austria, 2017. Available online: http:/ / www.ecoprof.at/index.php/faunaaquaticaaustriaca.html (accessed on 12 May 2021).

11. Schlosser, J.K. Fauna Kornjašah Trojedne Kraljevine; Yugoslav Academy of Sciences and Arts: Zagreb, Croatia, 1877; pp. 88-118. (In Croatian)

12. Apfelbeck, A. Fauna Insectorum Balcanica. Beiträge zur Kenntnis der Balkanfauna; Wissenschaftliche Mitteilungen aus Bosnien und der Hercegowina: Sarajevo, Bosnia and Herzegovina, 1894; Volume 2, pp. 24-32.

13. Mičetić Stanković, V.; Jäch, M.A.; Kučinić, M. Annotated checklist of Croatian riffle beetles (Coleoptera: Elmidae). Nat. Croat. Period. Musei Hist. Nat. Croat. 2015, 24, 93-109. [CrossRef]

14. Mičetić Stanković, V.; Jäch, M.A.; Ivković, M.; Stanković, I.; Kružić, P.; Kučinić, M. Spatio-temporal distribution and species traits of water beetles along an oligotrophic hydrosystem: A case study. Ann. Limnol. 2019, 55, 16. [CrossRef] 
15. Mičetić Stanković, V.; Bruvo Mađarić, B.; Jäch, M.A.; Kučinić, M. Elmis rietscheli Steffan, 1958 (Insecta: Coleoptera: Elmidae) in Croatia: First record and DNA barcoding. Nat. Croat. Period. Musei Hist. Nat. Croat. 2018, 27, 185-194. [CrossRef]

16. Mičetić Stanković, V.; Jäch, M.A.; Vučković, I.; Popijač, A.; Kerovec, M.; Kučinić, M. Ecological traits of water beetles in a karstic river from the Eastern Mediterranean region. Limnologica 2018, 71, 75-88. [CrossRef]

17. Novaković, B.B.; Mesaroš, G. First recent record of Macronychus quadrituberculatus Müller, 1806 (Elmidae: Coleoptera) in Serbia. Water Resour. Manag. 2014, 4, 35-37.

18. Novaković, B.B.; Teofilova, T.M.; Pandakov, P.G.; Živić, I. New distributional records of rare riffle beetles (Coleoptera: Elmidae) from the Balkan Peninsula. Arch. Biol. Sci. 2020, 72, 129-135. [CrossRef]

19. Novaković, B.B.; Marković, V.; Mesaroš, G.; Živić, I. The riffle beetle Macronychus quadrituberculatus Müller, 1806 (Coleoptera: Elmidae): Recent findings in Serbia with ecological notes. Biologia 2020, 75, 1891-1897. [CrossRef]

20. Mičetić Stanković, V.; Stanković, I.; Vilenica, M.; Delić, A.; Kučinić, M. Water Beetles (Insecta: Coleoptera) in Spring of the Dinaric Karst: Ecology and Biology; Croatian Natural History Museum: Zagreb, Croatia, 2022.

21. Matoničkin, I.; Pavletić, Z.; Tavčar, V.; Krkač, N. Limnološka istraživanja reikotopa i fenomena protočne travertinizacije u Plitvičkim jezerima. Prirodosl. Istraž. Acta Biol. 1971, 7, 1-88. (In Croatian)

22. Habdija, I.; Primc-Habdija, B.; Belinić, I. Functional community organization of macroinvertebrates in lotic habitats of the Plitvice Lakes. Acta Hydrochim. Hydrobiol. 1994, 22, 85-92. [CrossRef]

23. Zaitzev, P.A. Catalogue des Coléoptères Aquatiques des Familles des Dryopidae, Georyssidae, Cyathoceridae, Heteroceridae et Hydrophilidae, Horae Societatis Entomologicae Rossicae, Variis Sermonibus in Rossia Usitatis Editae; Besobrasovi \& Comp.: Saint Petersburg, Russia, 1908; Volume 38, pp. 283-420.

24. Chen, Z.; Auler, A.S.; Bakalowicz, M.; Drew, D.; Griger, F.; Hartmann, J.; Jiang, G.; Moosdorf, N.; Richts, A.; Stevanović, Z.; et al. The world karst aquifer mapping project: Concept, mapping procedure and map of Europe. Hydrogeol. J. 2017, 25, 771-785. [CrossRef]

25. Bonacci, O. Karst hydrology and water resources-Past, present and future. In Water for the Future: Hydrology in Perspective, Proceedings of the Rome Symposium, Rome, Italy, 20-22 October 1987; Rodda, J.C., Matalas, N.C., Eds.; International Association of Hydrological Sciences: Rome, Italy, 1987; pp. 205-213.

26. Reed, J.M.; Kryštufek, B.; Eastwood, W.J. The physical geography of the Balkans and nomenclature of place names. In Balkan Biodiversity; Griffiths, H.I., Kryštufek, B., Reed, J.M., Eds.; Springer: Dordrecht, The Netherlands, 2004; pp. 9-22. [CrossRef]

27. Bonacci, O.; Pipan, T.; Culver, D.C. A framework for karst ecohydrology. Environ. Geol. 2009, 56, 891-900. [CrossRef]

28. Sánchez-Fernández, D.; Abellán, P.; Velasco, J.; Millán, A. Selecting areas to protect the biodiversity of aquatic ecosystems in a semiarid Mediterranean region using water beetles. Aquat. Conserv. 2004, 14, 465-479. [CrossRef]

29. Bonacci, O.; Andrić, I. Karst spring catchment: An example from Dinaric karst. Environ. Earth Sci. 2015, 74, 6211-6223. [CrossRef]

30. Earman, S.; Dettinger, M. Potential impacts of climate change on groundwater resources-A global review. J. Water Clim. Chang. 2011, 2, 213-229. [CrossRef]

31. Nerantzaki, S.D.; Nikolaidis, N.P. The response of three Mediterranean karst springs to drought and the impact of climate change. J. Hydrol. 2020, 591, 125296. [CrossRef]

32. Gaston, K.J.; David, R. Hotspots across Europe. Biodivers. Lett. 1994, 2, 108-116. [CrossRef]

33. Kryštufek, B.; Buzan, E.V.; Hutchinson, W.F.; Hanfling, B. Phylogeography of the rare Balkan endemic Martino's vole, Dinaromys bogdanovi, reveals strong differentiation within the western Balkan Peninsula. Mol. Ecol. 2007, 16, 1221-1232. [CrossRef]

34. Previšić, A.; Walton, C.; Kučinić, M.; Mitrikeski, P.T.; Kerovec, M. Pleistocene divergence of Dinaric Drusus endemics (Trichoptera, Limnephilidae) in multiple microrefugia within the Balkan Peninsula. Mol. Ecol. 2009, 18, 634-647. [CrossRef]

35. Palandačić, A.; Bonacci, O.; Snoj, A. Molecular data as a possible tool for tracing groundwater flow in karst environment: Example of Delminichthys adspersus in Dinaric karst system. Ecohydrology 2011, 5, 791-797. [CrossRef]

36. Ivković, M.; Plant, A. Aquatic insects in the Dinarides: Identifying hotspots of endemism and species richness shaped by geological and hydrological history using Empididae (Diptera). Insect Conserv. Divers. 2015, 8, 302-312. [CrossRef]

37. Bregović, P.; Fišer, C.; Zagmajster, M. Contribution of rare and common species to subterranean species richness patterns. Ecol. Evol. 2019, 9, 11606-11618. [CrossRef]

38. Manenti, R.; Piazza, B. Between darkness and light: Spring habitats provide new perspectives for modern researchers on groundwater biology. Peer] 2021, 9, e11711. [CrossRef] [PubMed]

39. Lai, G.G.; Padedda, B.M.; Ector, L.; Wetzel, C.E.; Lugliè, A.; Cantonati, M. Mediterranean karst springs: Diatom biodiversity hotspots under the pressure of hydrological fluctuations and nutrient enrichment. Plant Biosyst. 2019, 154, 673-684. [CrossRef]

40. Hebert, P.D.N.; Cywinska, A.; Ball, S.L.; deWaard, J.R. Biological identifications through DNA barcodes. Proc. R. Soc. Lond. Ser. B Biol. Sci. 2003, 270, 313-322. [CrossRef] [PubMed]

41. Hendrich, L.; Morinière, J.; Haszprunar, G.; Hebert, P.D.N.; Hausmann, A.; Köhler, F.; Balke, M. A comprehensive DNA barcode database for Central European beetles with a focus on Germany: Adding more than 3500 identified species to BOLD. Mol. Ecol. Resour. 2015, 15, 795-818. [CrossRef] [PubMed]

42. Jovović, L.; Bruvo Mađarić, B.; Mičetić Stanković, V.; Jäch, M.A.; Kučinić, M. Phylogeny and phylogeography of genus Elmis (Coleoptera, Elmidae) in karstic running waters in southeastern Europe. In Proceedings of the 12th Croatian Biological Congress with International Participation, Sveti Martin na Muri, Croatia, 18-23 September 2015; pp. 173-174. 
43. Múrria, C.; Bonada, N.; Vellend, M.; Zamora-Muñoz, C.; Alba-Tercedor, J.; Elisa Sainz-Cantero, C.; Garrido, J.; Acosta, R.; El Alami, M.; Barquín, J.; et al. Local environment rather than past climate determines community composition of mountain stream macroinvertebrates across Europe. Mol. Ecol. 2017, 26, 6085-6099. [CrossRef]

44. German Barcode of Life. 2021. Available online: https://bolgermany.de/home/en/german-barcode-of-life-2 (accessed on 23 February 2021).

45. Austrian Barcode of Life. 2021. Available online: https://www.abol.ac.at/ (accessed on 23 February 2021).

46. Ratnasingham, S.; Hebert, P.D.N. A DNA-based registry for all animal species: The Barcode Index Number (BIN) system. PLoS ONE 2013, 8, e66213. [CrossRef]

47. Fossen, E.I.; Ekrem, T.; Nilsson, A.N.; Bergsten, J. Species delimitation in northern European water scavenger beetles of the genus Hydrobius (Coleoptera, Hydrophilidae). ZooKeys 2016, 564, 71-120. [CrossRef]

48. Bilton, D.T.; Turner, L.; Foster, G.N. Frequent discordance between morphology and mitochondrial DNA in a species group of European water beetles (Coleoptera: Dytiscidae). PeerJ 2017, 5, e3076. [CrossRef]

49. Bilton, D.T.; Ribera, I. A revision of Meladema diving beetles (Coleoptera, Dytiscidae), with the description of a new species from the central Mediterranean based on molecules and morphology. ZooKeys 2017, 702, 45-112. [CrossRef] [PubMed]

50. Joffre, S.; Stanners, D. Europe: The continent. In Europe's Environment: The Dobř̆̌̆ Assessement; Stanners, D., Bourdeau, P., Eds.; European Environment Agency: Copenhagen, Denmark, 1995; pp. 18-24.

51. European Environment Agency 2021. Biogeographical Regions in Europe. Available online: https:/ / www.eea.europa.eu/dataand-maps/figures/biogeographical-regions-in-europe-2 (accessed on 26 February 2021).

52. Bilandžija, H.; Morton, B.; Podnar, M.; Ćetković, H. Evolutionary history of relict Congeria (Bivalvia: Dreissenidae): Unearthing the subterranean biodiversity of the Dinaric Karst. Front. Zool. 2013, 10, 5. [CrossRef]

53. Gottstein, S.; Žganec, K.; Kerovec, M.; Ternjej, I.; Lajtner, J.; Mihaljević, Z.; Popijač, A.; Previšić, A.; Ivković, M.; Mičetić, V. ThePotential Effect of the Hydroelectric Power Plant Lešce on Spring Macroinvertebrate Assemblages of the Upper Course of the Gojačka Dobra River; University of Zagreb, Faculty of Science: Zagreb, Croatia, 2009. (In Croatian)

54. Kerovec, M.; Kučinić, M. Bioindikatorska i Ekološka Obilježja te Rasprostranjenost i Gustoća Populacija Faune Tulara (Trichoptera, Insecta) duž Toka Rijeke Cetine; University of Zagreb, Faculty of Science: Zagreb, Croatia, 2007; 158p. (In Croatian)

55. Šerić Jelaska, L.; Temunović, M.; Mičetić Stanković, V.; Hlavati, D. Ground beetles, diving beetles, whirligig beetles, water scavengers, riffle beetles, scarab beetles, dung beetles, hister beetles, carrion beetles-The beetles (Insecta, Coleoptera) of the travertine waterfalls, Mediterranean ponds and grasslands of Krka National Park. In Abstract Book: Vision and Challenges of Managing Protected Natural Areas in the Republic of Croatia: Active Protection and Sustainable Management in Krka National Park, Šibenik, Croatia; Marguš, D., Ed.; The Public Institution of Krka National Park: Šibenik, Croatia, 2017; pp. $208-247$.

56. Mičetić Stanković, V. Water Beetles (Insecta: Coleoptera) in Microhabitats of Karstic Springs and Rivers. Ph.D. Thesis, Faculty of Science, University of Zagreb, Zagreb, Croatia, 2012.

57. Hynes, H.B.N. The Ecology of Running Waters; University of Toronto Press: Toronto, ON, Canada, 1970; p. 555. [CrossRef]

58. Berthélemy, C. Elmidae de la région paléarctique occidentale: Systématique et répartition (Coleoptera Dryopoidea). Ann. Limnol. 1979, 15, 1-102. [CrossRef]

59. Ter Braak, C.J.F. Ordination. In Data Analysis in Community and Landscape Ecology; Jongman, R.H.G., ter Braak, C.J.F., van Tongeren, O.F.R., Eds.; Cambridge University Press: Cambridge, UK, 1995; pp. 91-173.

60. SPSS Inc. SPSS Statistics for Windows, Version 17.0; Released 2008; SPSS Inc.: Chicago, IL, USA, 2008.

61. Clarke, K.R.; Gorley, R.N. PRIMER v6: User Manual/Tutorial (Plymouth Routines in Multivariate Ecological Research); PRIMER-E Ltd.: Plymouth, UK, 2006.

62. Grapher ${ }^{T M}$; Golden Software, LLC.: Golden, CO, USA, 2021. Available online: www.goldensoftware.com (accessed on 24 September 2021).

63. Folmer, O.; Black, M.; Wr, H.; Lutz, R.; Vrijenhoek, R. DNA primers for amplification of mitochondrial Cytochrome C oxidase subunit I from diverse metazoan invertebrates. Mol. Mar. Biol. Biotechnol. 1994, 3, 294-299.

64. Geneious 8.1.4. Available online: https://www.geneious.com (accessed on 15 March 2021).

65. BOLD Identification Tool. Available online: https://www.boldsystems.org/index.php/IDs (accessed on 20 May 2021).

66. Katoh, K.; Rozewicki, J.; Yamada, K.D. MAFFT online service: Multiple sequence alignment, interactive sequence choice and visualization. Brief. Bioinform. 2019, 20, 1160-1166. [CrossRef]

67. Multiple Alignment Program for Amino Acid or Nucleotide Sequences. Available online: https://mafft.cbrc.jp/alignment/ server/index.html (accessed on 29 May 2021).

68. Kumar, S.; Stecher, G.; Tamura, K. MEGA7: Molecular Evolutionary Genetics Analysis Version 7.0 for Bigger Datasets. Mol. Biol. Evol. 2016, 33, 1870-1874. [CrossRef] [PubMed]

69. Guindon, S.; Dufayard, J.-F.; Lefort, V.; Anisimova, M.; Hordijk, W.; Gascuel, O. New Algorithms and Methods to Estimate Maximum-Likelihood Phylogenies: Assessing the Performance of PhyML 3.0. Syst. Biol. 2010, 59, 307-321. [CrossRef] [PubMed]

70. PhyML 3.0: New Algorithms, Methods and Utilities. Available online: http://www.atgc-montpellier.fr/phyml (accessed on 10 June 2021).

71. Lefort, V.; Longueville, J.-E.; Gascuel, O. SMS: Smart Model Selection in PhyML. Mol. Biol. Evol. 2017, 34, 2422-2424. [CrossRef] [PubMed] 
72. Anisimova, M.; Gascuel, O. Approximate likelihood-ratio test for branches: A fast, accurate, and powerful alternative. Syst. Biol. 2006, 55, 539-552. [CrossRef]

73. FigTree v.1.4.3. Available online: http://tree.bio.ed.ac.uk/software/figtree/ (accessed on 15 June 2021).

74. Olmi, M. Fauna d'Italia. Coleoptera: Dryopidae, Elminthidae; Edizioni Calderini: Bologna, Italy, 1976; Volume XII, p. 272.

75. Pentinsaari, M.; Hebert, P.D.N.; Mutanen, M. Barcoding beetles: A regional survey of 1872 species reveals high identification success and unusually deep interspecific divergences. PLoS ONE 2014, 9, e108651. [CrossRef]

76. Oláh, J.; Andersen, T.; Chvojka, P.; Coppa, G.; Graf, W.; Ibrahimi, H.; Previšić, A.; Valle, M. The Potamophylax nigricornis group (Trichoptera, Limnephilidae): Resolution of phylogenetic species by fine structure analysis. Opusc. Zool. Bp. 2013, 44, 167-200.

77. Hebauer, F. Entwurf einer Entomosoziologie aquatischer Coleoptera in Mitteleuropa (Insecta, Coleoptera, Hydradephaga, Hydrophiloidea, Dryopoidea). Lauterbornia 1994, 19, 43-76.

78. Hebauer, F. Katalog der bayerischen Wasserkäfer, ihrer Ökologie, Verbreitung, Gefährdung. Ber. Akad. Nat. Schutz Landsch. Pfl. 1994, 18, 47-59.

79. Brojer, M.; Jäch, M.A.; Kodada, J.; Moog, O. Coleoptera: Water Beetles s.l. In Fauna Aquatica Austriaca, 3rd ed.; Moog, O., Hartmann, A., Eds.; Federal Ministry of Agriculture, Forestry, Environment and Water Management: Wien, Austria, 2017 ; p. 49.

80. Zollhöfer, J.M. Spring Biotopes in Northern Switzerland: Habitat Heterogeneity, Zoobenthic Communities and Colonization Dynamics. Ph.D. Thesis, Swiss Federal Institute of Science and Technology, Zürich, Switzerland, 1999.

81. Smith, H.; Wood, P.J. Flow permanence and macroinvertebrate community variability in limestone spring systems. Hydrobiologia 2002, 487, 45-58. [CrossRef]

82. Mičetić Stanković, V. Croatian Natural History Museum, Zagreb, Croatia. Personal observation.

83. Bournaud, M.; Richoux, P.; Usseglio-Polatera, P. An approach to the synthesis of qualitative ecological information from aquatic coleoptera communities. Regul. Rivers Res. Manag. 1992, 7, 165-180. [CrossRef]

84. Eyre, M.D.; Pilkington, J.G.; Carr, R.; McBlane, R.P.; Rushton, S.P.; Foster, G.N. The running-water beetles (Coleoptera) of a river catchment in northern England. Hydrobiologia 1993, 264, 33-45. [CrossRef]

85. Berthélemy, C.; de Riols, J. Les larves d' Elmis du groupe d' E. maugetii (Coléoptères Drypoidea). Ann. Limnol. 1965, 1, 21-38. [CrossRef]

86. Elliott, J.M. Critical periods in the life cycle and the effects of a severe spate vary markedly between four species of elmid beetles in a small stream. Freshw. Biol. 2006, 51, 1527-1542. [CrossRef]

87. Giller, P.S.; Malmqvist, B. The Biology of Streams and Rivers, 1st ed.; Oxford University Press: Oxford, UK, $1998 ;$ p. 304.

88. Jäch, M.A. Daytime swarming of rheophilic water beetles in Austria (Coleoptera: Elmidae, Hydraenidae, Haliplidae). Latissimus 1997, 9, 10-11.

89. Jäch, M.A. Observations on rheophilic water beetles swarming in lower Austria in 2003 (Hydraenidae, Elmidae). Latissimus 2003, $1,20-22$.

90. Seagle, H.H. Flight periodicity and emergence patterns in the Elmidae (Coleoptera: Dyropoidea). Ann. Entomol. Soc. Am. 1980, 73, 300-306. [CrossRef]

91. Girondot, M.; Pieau, C. Effects of sexual differences of age at maturity and survival on population sex ratio. Evol. Ecol. 1993, 7, 645-650. [CrossRef]

92. Papach, A.; Gonthier, J.; Williams, G.R.; Neumann, P. Sex ratio of small hive beetles: The role of pupation and adult longevity. Insects 2019, 10, 133. [CrossRef]

93. Miserendino, M.L.; Archangelsky, M. Aquatic coleoptera distribution and environmental relationships in a large Patagonian River. Int. Rev. Hydrobiol. 2006, 91, 423-437. [CrossRef]

94. Matoničkin, I.; Pavletić, Z. Hidrologija protočnog sistema Plitvičkih jezera i njegove ekološko-biocenološke značajke. Carsus Iugosl. 1967, 5, 83-126. (In Croatian)

95. Habdija, I.; Primc-Habdija, B.; Matoničkin, R.; Kučinić, M.; Radanović, I.; Miliša, M.; Mihaljević, Z. Current velocity and food supply as factors affecting the composition of macroinvertebrates in bryophyte habitats in karst running water. Biologia 2004, 59, 577-593.

96. Brown, H.P. Biology of riffle beetles. Annu. Rev. Entomol. 1987, 32, 253-273. [CrossRef]

97. Bonada, N.; Rieradevall, M.; Prat, N. Macroinvertebrate community structure and biological traits related to flow permanence in a Mediterranean river network. Hydrobiologia 2007, 589, 91-106. [CrossRef]

98. Datry, T.; Larned, S.T.; Tockner, K. Intermittent rivers: A challenge for freshwater ecology. Bioscience 2014, 64, 229-235. [CrossRef]

99. Vilenica, M.; Mičetić Stanković, V.; Sartori, M.; Kučinić, M.; Mihaljević, Z. Environmental factors affecting mayfly assemblages in tufa-depositing habitats of the Dinaric Karst. Knowl. Manag. Aquat. Ec. 2017, 418, 14. [CrossRef]

100. Vilenica, M.; Ivković, M.; Sartori, M.; Mihaljević, Z. Mayfly emergence along an oligotrophic Dinaric karst hydrosystem: Spatial and temporal patterns, and species-environment relationship. Aquat. Ecol. 2017, 51, 417-433. [CrossRef]

101. Ortega, J.C.G.; Geijer, J.; Bergsten, J.; Heino, J.; Herrmann, J.; Johansson, F.; Bini, L.M. Spatio-temporal variation in water beetle assemblages across temperate freshwater ecosystems. Sci. Total Environ. 2021, 792, 148071. [CrossRef]

102. Iglesias, A.; Garrote, L.; Flores, F.; Moneo, M. Challenges to manage the risk of water scarcity and climate change in the Mediterranean. Water Resour. Manag. 2007, 21, 775-788. [CrossRef] 